\title{
Kinematics of subduction in the Ibero-Armorican arc constrained by 3D microstructural analysis of garnet and pseudomorphed lawsonite porphyroblasts from Île de Groix (Variscan belt)
}

\author{
Domingo G. A. M. Aerden ${ }^{1,2}$, Alejandro Ruiz-Fuentes ${ }^{1}$, Mohammad Sayab ${ }^{3}$, and Aidan Forde \\ ${ }^{1}$ Departamento de Geodinámica, Universidad de Granada, Granada, Spain \\ ${ }^{2}$ Instituto Andaluz de Ciencias de la Tierra, CSIC/Universidad de Granada, Granada, Spain \\ ${ }^{3}$ Geological Survey of Finland, Espoo, Finland \\ ${ }^{4}$ Saorgus Energy Ltd, Kerry, Ireland
}

Correspondence: Domingo G. A. M. Aerden (aerden@ugr.es)

Received: 9 October 2020 - Discussion started: 19 October 2020

Revised: 26 January 2021 - Accepted: 24 February 2021 - Published: 26 April 2021

\begin{abstract}
The small island of Groix in southern Brittany, France, is well known for exceptionally well-preserved outcrops of Variscan blueschists, eclogites, and garnetiferous mica schists that mark a Late Devonian suture between Gondwana and Armorica. The kinematics of polyphase deformation in these rocks is reconstructed based on 3D microstructural analysis of inclusion trails within garnet and pseudomorphed lawsonite porphyroblasts using differently oriented thin sections and X-ray tomography. Three sets of inclusion trails striking NE-SW, NNW-SSE, and WNWESE are recognized and interpreted to witness a succession of different crustal shortening directions orthogonal to these strikes. The curvature sense of sigmoidal and spiral-shaped inclusion trails of the youngest set is shown to be consistent with northwest and northward subduction of Gondwana under Armorica, provided that these microstructures developed by overgrowth of actively forming crenulations without much porphyroblast rotation. Strongly non-cylindrical folds locally found on the island are reinterpreted as foldinterference structures instead of having formed by progressive shearing and fold-axis reorientation. Six samples of a lower-grade footwall unit of the Groix ophiolitic nappe (Pouldu schists) were also studied. Inclusion trails in these rocks strike E-W, similar to the youngest set recognized on Groix island. They record Carboniferous N-S shortening during continental collision. These new microstructural data from southern Brittany bear a strong resemblance to earlier measured in inclusion-trail orientations in the northwestern
\end{abstract}

Iberia Massif. A best fit between both regions suggests not more than about $15^{\circ}$ anticlockwise rotation of Iberia during the Cretaceous opening of the Gulf of Biscay.

\section{Introduction}

Structural analysis in metamorphic terrains is traditionally based on a combination of geological mapping, study of structures in outcrops, and microstructures in thin sections that are commonly cut parallel to the stretching lineation aimed at determining a shear sense. Not rarely does this approach produce ambiguous or even paradoxical results (e.g. Zhang and Fossen, 2020), apart from not allowing access to the kinematics of strongly overprinted early formed fabrics. A major breakthrough in this state of affairs was claimed by Bell (1985), Bell et al. (1986), and Bell and Johnson (1989) after recognizing the polyphase origin of inclusion-trail patterns that were previously assumed to have formed by progressive shearing and porphyroblast rotation (e.g. Zwart, 1962; Spry, 1963; Rosenfeld, 1970). Sigmoidal and spiralshaped inclusion trails were reinterpreted as representing multiple crenulations that became sequentially fixed within non-rotating porphyroblasts with episodic growth histories. The lack of porphyroblast rotation would have resulted from the general micro-partitioning of deformation between cleavage planes (accommodating shear-strain components) and microlith domains and the preferential nucleation of porphy- 
roblasts within the latter (Bell, 1985; Aerden, 1995; Fay et al., 2008). Axes of inclusion-trail curvature in this view are not controlled by shearing directions but by the intersection of two or more foliations causing crenulation and folding and consequently referred to as "foliation-intersection/inflexion axes" abbreviated as "FIA" (Bell et al., 1992, 1995; Stallard et al., 2003). Another major difference with the classic model is that the curvature sense (clockwise or anticlockwise) of inclusion trails being determined by the ( $\mathrm{S}$ or $\mathrm{Z}$ ) asymmetry of overgrown crenulations indicates an opposite shear sense as would have been originally deduced (see Fig. 1a, b).

The above conceptual changes regarding the significance of porphyroblast inclusion trails prompted extensive collection of orientation data for these microstructures in various metamorphic belts, which revealed their regional-scale consistency and close relationship to large-scale tectonic processes (e.g. Bell et al., 1998; Bell and Welch, 2002; Sayab, 2005; Ali, 2010; Shah et al., 2011; Aerden, 1994, 1998, 2004; Aerden et al., 2013; Kim and Ree, 2013; Abu Sharib and Bell, 2011; Abu Sharib and Sanislav, 2013; Aerden and Sayab, 2017). The methodological novelty of this research resides in the integration of quantitative microstructural data derived from precisely oriented thin sections of different samples in an external (geographical) reference frame. For this purpose, thin sections are systematically cut in fixed orientations relative to geographic coordinates, independent of the (variable) orientations of the macroscopic lineation and foliation in each sample. Vertical and/or horizontal thin section orientations are usually chosen as these represent smallscale true cross sections and maps that can be directly compared with their larger-scale equivalents.

Aerden (2004) pioneered this approach in NW Iberia where he distinguished four sets of inclusion trails, each with a specific and regionally consistent trend. The E-W trend of the oldest set was interpreted to record N-S-directed compression and subduction with unknown polarity. This was followed by several changes in the direction of crustal shortening that produced the three younger inclusion-trail sets. The youngest two sets, trending NE-SW and WNW-ESE, were shown to correlate with regional-scale fold-interference patterns developed throughout the Iberian Massif, and this was key to the discovery of the partially blind Central Iberian Arc (Aerden, 2004; Martinez Catalán et al., 2011).

In this paper we report a similar microstructural study in the Armorican Massif focusing on high-pressure metabasites of Île de Groix, but also paying attention to a lowergrade footwall unit known as the Pouldu schists. The island of Groix (ca. $15 \mathrm{~km}^{2}$ ) is a national reserve famous for exceptionally well-preserved coastal outcrops of Variscan blueschists, eclogites, and interlayered garnetiferous mica schists (Audren et al., 1993). These are generally accepted to represent the remains of the floor of a narrow ocean that, in the late Silurian and lower Devonian, separated Gondwana in the south from the Armorica microplate to the north. Closure of this ocean by subduction of the margin of Gondwana pro- duced high-pressure metamorphism dated $370-360 \mathrm{Ma}$ on Île de Groix (Bosse et al., 2005). In NW Iberia, a similar ophiolitic unit is recognized and correlated with the one exposed on Groix island (Arenas et al., 1995; Diaz García et al., 1999; Ballèvre et al., 2009, 2013).

The polarity and kinematics of ophiolite emplacement have remained poorly constrained by (micro)structural data. Indeed, not much appears to have changed since Quinquis et al. (1978) wrote

\section{the bulk sense of shear on Groix has not yet been determined unequivocally, but may perhaps be de- duced from systematic analyses of fold asymmetry and of microstructures in and around syntectonic garnets. The significance of glaucophane orienta- tion in the basic rocks of Groix also needs to be studied: the orientation is extremely variable and may not be simply related to a shear direction.}

Precisely along these lines of suggested further research, we have performed detailed 3D microstructural analyses of 10 garnetiferous blueschist samples of the Île de Groix ophiolitic nappe, 4 samples of albite-porphyroblast, bearing greenschists (Pouldu schists) of a footwall unit cropping out along the mainland coast, plus 2 kyanite-staurolite schists collected further inland from the North Armorican Zone (Fig. 2). Integrated with structural field data from previous workers, the new microstructural data indicate a polyphase deformation history masked by a seemingly simple L-S fabric. Implications for the formation mechanism of sheath folds (Île de Groix is one of the main type locations) are discussed and for variations in the direction of Variscan subduction with time. A possible correlation is proposed between inclusion-trail trends in NW Iberia and in the Armorican Massif, which if correct, implies not more than $15^{\circ}$ anticlockwise rotation of Iberia during opening of the Gulf of Biscay.

\section{Geological setting and previous work}

The Variscan (or Hercynian) orogeny took place in the Devonian and Carboniferous as a consequence of GondwanaLaurussia convergence with the Armorica and Avalonia microcontinents occupying intermediate positions (e.g. Matte, 2001). The resulting closure of oceanic domains created multiple ophiolitic sutures, whose precise location, timing, and correlation continue to be a major research topic (e.g. Azor et al., 2008; Faure et al., 2008; Ballèvre et al., 2009; Arenas et al., 2016). The high-pressure rocks of Île de Groix are part of a partially submerged ophiolitic klippen of a thrust nappe that separates Armorican crustal units in the hanging wall (outcropping in the Central and North Armorican domains) from Gondwana-derived units in the footwall cropping out extensively in the South Armorican Domain and NW Iberia (Fig. 2). Mineral and stretching lineations have 
(a)

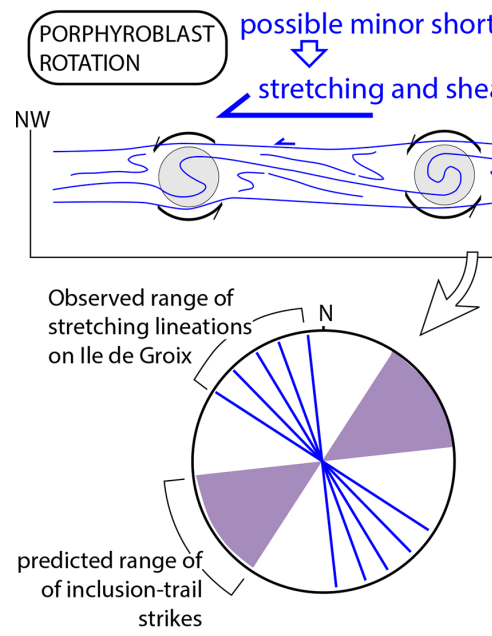

(b)

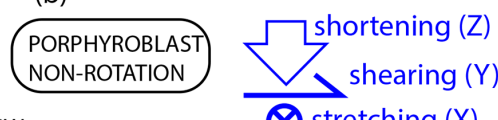

sw $\underset{\otimes \text { stretching }(X)}{\longrightarrow}$

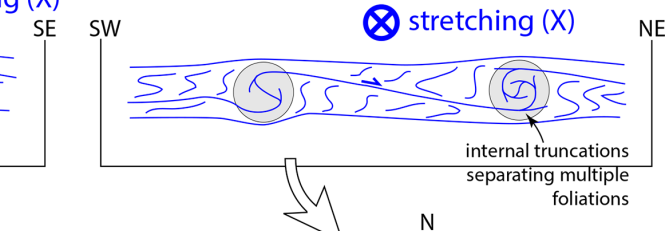

(c) MEASURED inclusion-
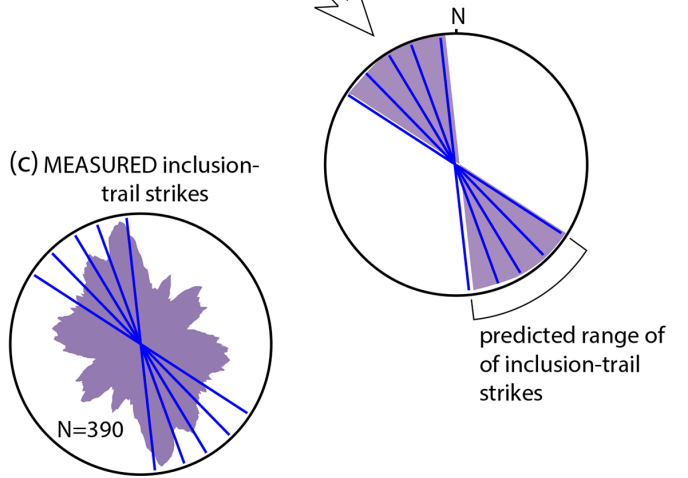

Figure 1. (a) Traditional rotational interpretation of sigmoidal and spiral-shaped inclusion trails and the range (purple) of inclusion-trail strikes predicted by this model in rocks from Île de Groix. (b) "Non-rotational" interpretation of inclusion trails formed by overgrowth of successive crenulation cleavages and the predicted range of inclusion-trail strikes for Île de Groix. (c) Actually measured inclusion-trail strikes in 10 samples from Île de Groix. Note that they better match the predictions of the non-rotation model.

an average $\mathrm{N}-\mathrm{S}$ trend in the east and southeast of the island, changing gradually to NW-SE further north and west. Bosse et al. (2002) proposed a thrust contact between garnetiferous eclogites, blueschists, and mica schists outcropping in the eastern part of the island (Fig. 3a), overlying a lower-grade (albite-epidote facies) unit outcropping in the west containing scarce garnet porphyroblasts (Triboulet, 1974; Schulz et al., 2001). Peak metamorphic conditions are estimated at $475^{\circ} \mathrm{C}$ and $18-20 \mathrm{kbar}$ in the upper unit and $450^{\circ} \mathrm{C}$ and $12-$ $15 \mathrm{kbar}$ in the lower unit (Bosse et al. 2002; Ballèvre et al., 2003).

The general tectono-metamorphic zonation of the Armorican Massif has led most workers to accept a north-dipping subduction zone associated with south-verging thrusting (e.g. Matte, 2001; Faure et al., 2008; Ballèvre et al., 2009, 2013; Philippon et al., 2009; Fig. 2b). However, structural data have not allowed the independent confirmation of this and, in fact, have yielded conflicting results. Lagarde (1980) concluded NW-directed thrusting from shear criteria in the Champtoceaux Complex (Fig. 2a), suggesting southeast-directed subduction. A similar kinematic was deduced on Île de Groix from rotated snowball garnets and quartz $c$-axis fabrics by Quinquis (1980), Quinquis and Choukroune (1981), and Cannat (1985). To reconcile this with north-dipping subduction, Quinquis and Choukroune (1981) proposed that this shear sense corresponds to back-thrusting and ophiolite obduction, but little independent evidence has been presented to support this model.
Quinquis (1980) noticed that shear bands (C and $C^{\prime}$ planes) on Île de Groix indicate opposite shear senses that could not be clearly linked to different metamorphic conditions and were therefore interpreted as conjugate sets. Shelley and Bossière (1999) endorsed this and showed that quartz fabrics studied in 57 samples also record about equal amounts of opposite shear senses. From this they concluded that the main foliation and lineation of Île de Groix formed by coaxial vertical shortening in a period of crustal extension and exhumation. In contrast, Philippon et al. (2009) recently argued a consecutive origin of a first set of top-to-the-SW shear bands related to prograde metamorphism, followed by a second top-to-the-north set during retrogression. However, they did not resolve the conflict this poses with respect to topto-the-north shearing indicated by "rotated" garnets, which clearly formed during prograde metamorphism (Bosse et al., 2002; Ballèvre et al., 2003).

\section{Microstructural analysis using vertical and horizontal thin sections}

A total of 138 oriented thin sections were studied from 33 oriented samples: 20 from Île de Groix, 9 from the Pouldu schists and an equivalent unit in the Baye d'Audièrne (Tréogat formation), and 4 from the Central Armorican Zone (Fig. 2). Their precise location can be consulted in the Supplement provided with this paper. Initially, a single horizontal thin section was cut of each to evaluate the interest of the rock 
(a)

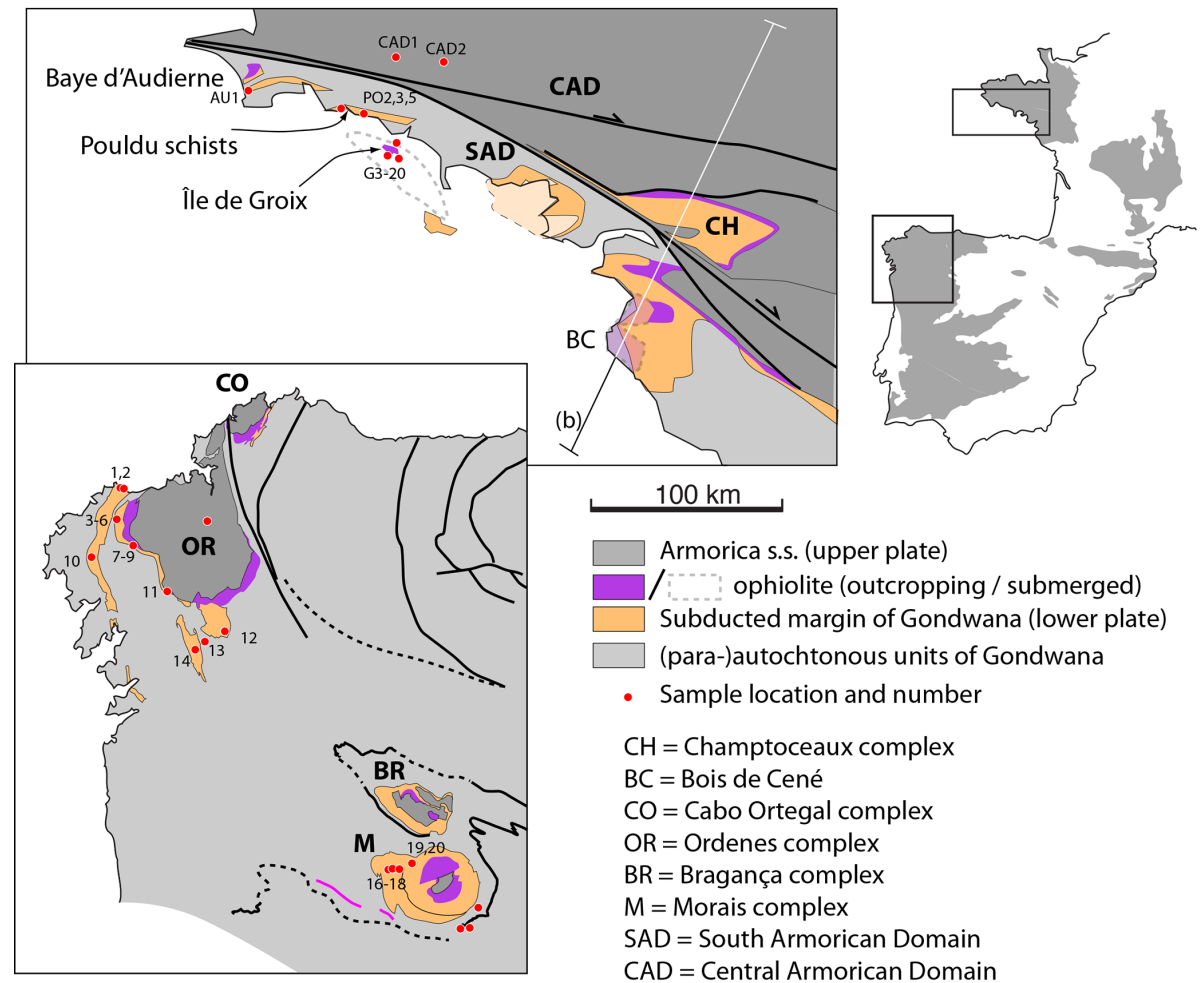

$\mathrm{S}$

(b)

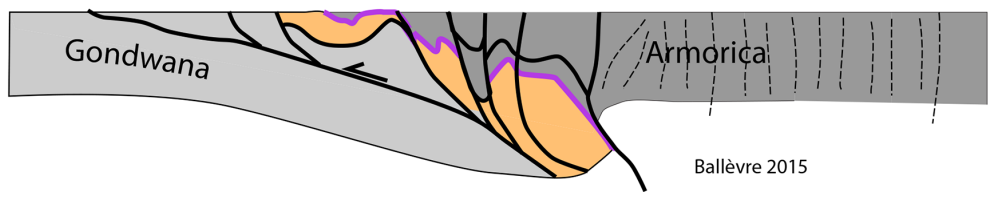

Figure 2. (a) Simplified geological maps of southern Brittany and NW Iberia showing the location of ophiolite outcrops and samples studied herein and by Aerden (2004) in NW Iberia. (b) Schematic N-S cross section after Ballèvre et al. (2013) showing the structural relationships between tectonic units in the Variscan orogen.

for further study and to measure the strike of inclusion trails (relative to geographic coordinates). The latter only proved possible in about half of the samples, as the other half contain garnets or plagioclase porphyroblasts that are too altered or have poorly developed inclusion trails. Seven Île de Groix samples containing the most promising inclusion trails were studied further in six vertical thin sections striking N0, N30, N60, N90, N120, and N150 aimed at constraining the orientation of inclusion-trail curvature axes (i.e. FIA; see Introduction) and record their curvature sense.

\subsection{Strike of inclusion trails in Île de Groix blueschist samples}

Inclusion-trail strikes were measured in garnet porphyroblasts of 10 samples from three areas of Île de Groix, all pertaining to the high-grade eastern domain of the island or "upper unit" of Bosse et al. (2002; Fig. 3a). The data are plotted in moving-average rose diagrams (Fig. 3b) made with the computer program "MARD" of Munro and Blenkinsop (2012). As pointed out by these authors, moving-average rose diagrams reveal the distribution of modal maxima more accurately than their conventional binned equivalents.

Stretching lineations in the high-grade domain are associated with a gently dipping or subhorizontal composite foliation. Therefore, if porphyroblasts rotated in the direction of the lineation during growth, then they can be expected to have developed inclusion trails broadly striking orthogonal to that lineation (Fig. 1a). Our measurements, however, show exactly the opposite: a main NNE-SSW maximum subparallel to stretching lineations and fold axes (Fig. 1c). This agrees better with a "non-rotational" origin of inclusion trails via overgrowth of successive crenulations, and this is supported further by truncational relationships commonly seen between inclusion trails in porphyroblast cores versus rims (Fig. 4a and b). Automatic orientation analysis of the 
(a)

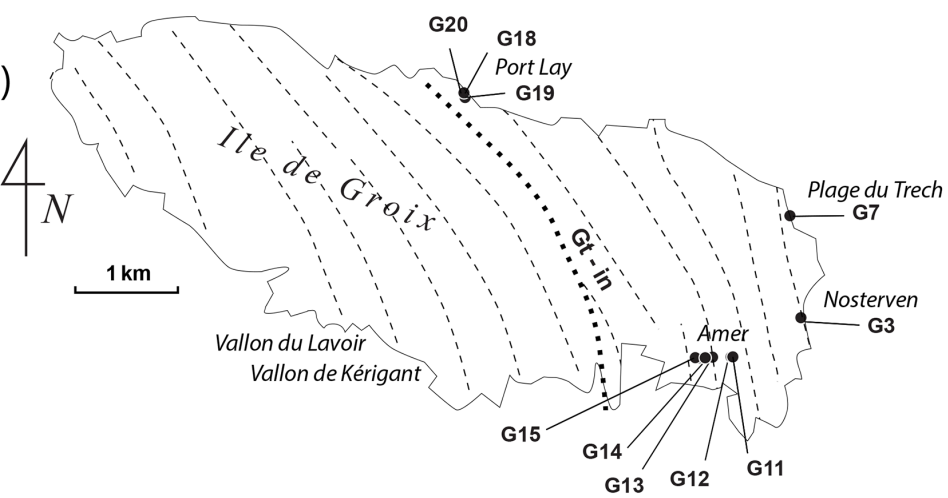

(b)

INCLUSION-TRAIL STRIKES AND AVERAGE FIAS - ILE DE GROIX

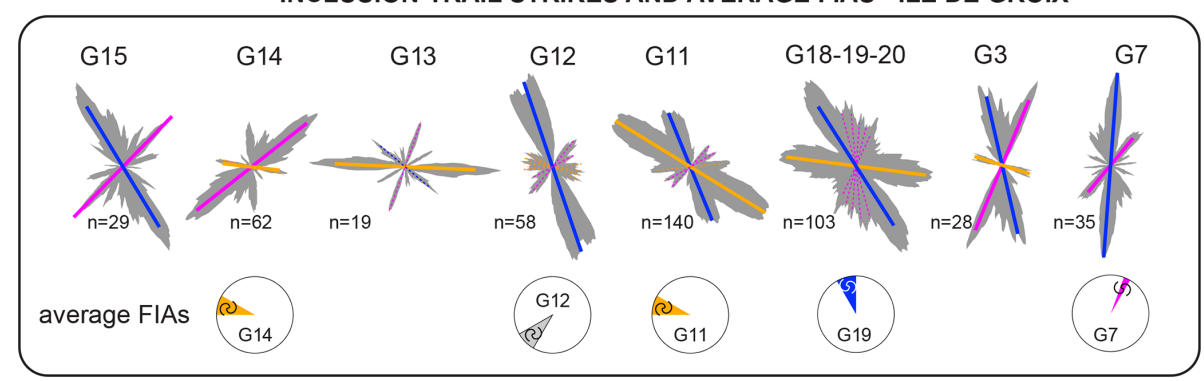

(c)

POULDU AND TRÉOGAT SCHISTS (Fig. 1)

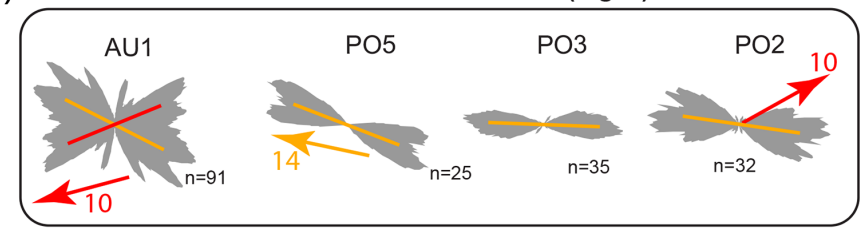

CENTRAL ARMORICAN DOMAIN (Fig. 1)

(d)
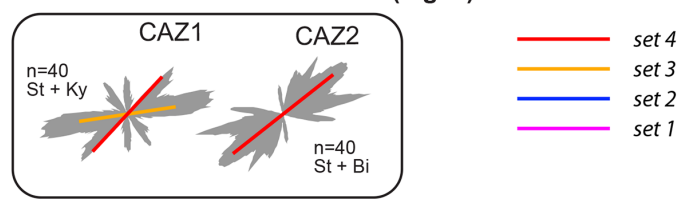

Figure 3. (a) Stretching lineation pattern in Île de Groix and sample locations. (b) Moving-average rose diagrams for inclusion-trail strikes. Pie chart symbols in circles give the average trend and plunge direction of FIAs in samples as determined from radial sets of thin sections. Small spirals inside these pie charts indicate the curvature sense of inclusion trails as seen when viewing down FIA plunge (anticlockwise in G14, G12, G11; clockwise in G19 and G7). Pink, blue, yellow, and red trend lines code for four different inclusion trail sets distinguished in this paper from older to younger. (c) Inclusion-trail strikes in Pouldu schist samples and Tréogat formation (AU1). Arrows represent fold axes measured in the outcrop. (d) Data from two staurolite-kyanite schists of the Central Armorican Domain.

inclusion-trail patterns pictured in these figures using the image analysis software package Fiji (Schindelin et al., 2012) reveals their bimodal preferred orientations reminiscent of the subvertical and subhorizontal preferred orientations of inclusion trails previously reported in other metamorphic regions (e.g. Bell et al., 1992; Hayward, 1992; Aerden, 1994, 1998, 2004; Mares, 1998; Stallard and Hickey, 2001; Bell and Sapkota, 2012; Sayab, 2005; Shah et al., 2011; Aerden and Ruiz-Fuentes, 2020). These authors all interpreted this to reflect alternations between orogenic shortening and gravitational collapse, but a somewhat different explanation will be proposed in Sect. 4.4 based on additional 3D data obtained by X-ray tomography.

\subsection{Inclusion-trail curvature sense and genetic implications}

Quinquis and Choukroune (1981) reported that out of a total of 29 thin sections studied (presumably all cut parallel to the stretching lineation), 26 contained sigmoidal or spiralshaped inclusion trails indicating top-to-the-north shearing. Since these authors assumed the rotational inclusion-trail 
(a) Sample G-7
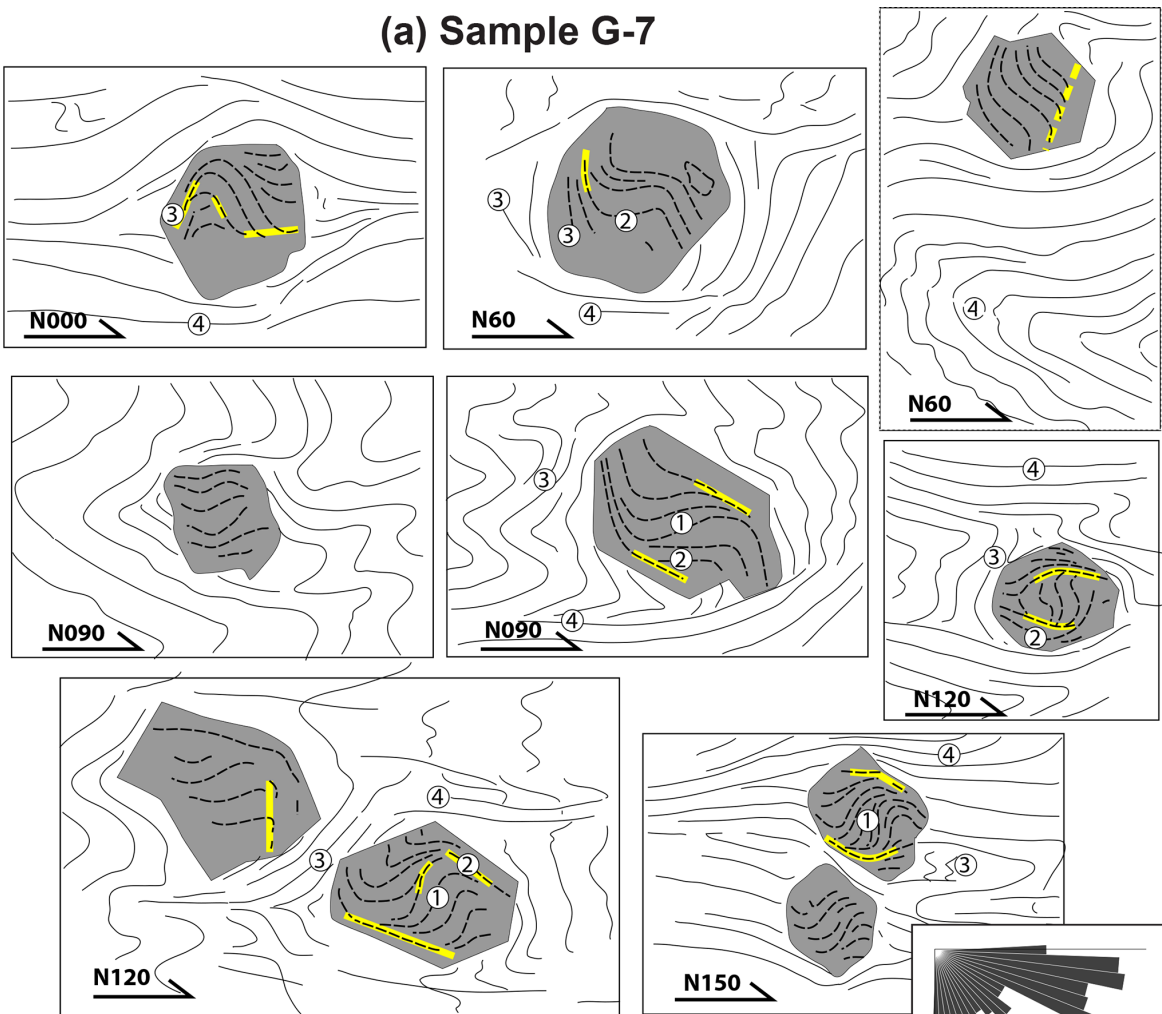

(b) Sample G-14
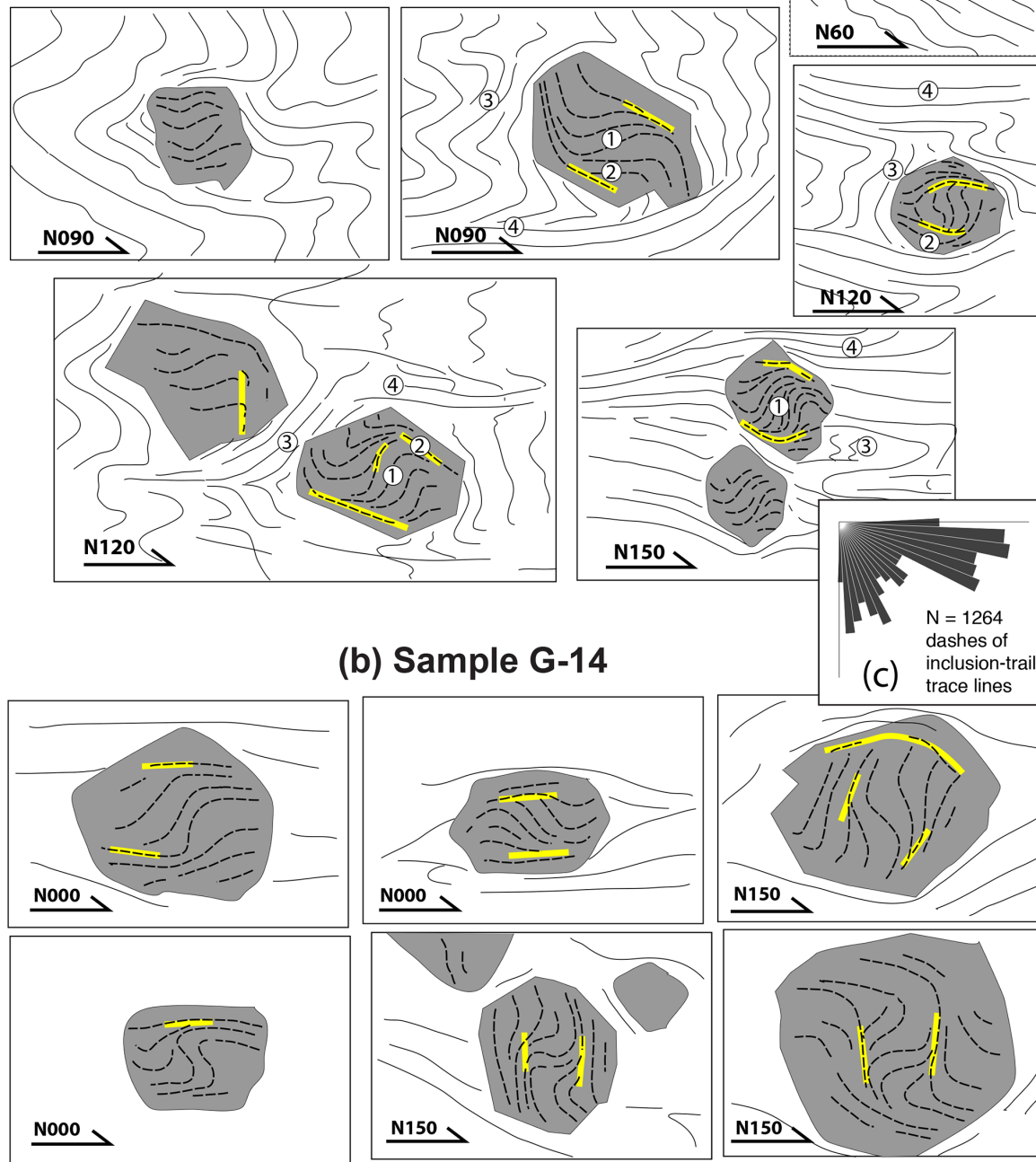

(c) inclusion-trail
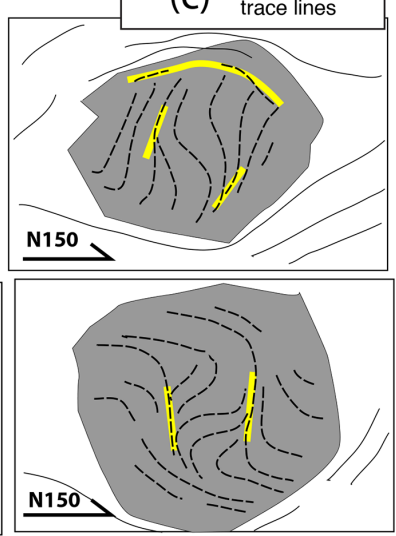

Figure 4. (a, b) Line drawings of inclusion trails and associated truncations (yellow lines) in differently striking vertical thin sections of G7 and G14. Half arrows indicate the strike of each section and way up. (c) Binned rose diagram plotting the angles of all dashes representing inclusion trails in (a) and (b) as measured with the "Analyse Particle" tool of Fiji. The broadly bimodal distribution reflects the presence of two or more sets of inclusion-trail planes, consistent with overgrowth of successive crenulation cleavages rather than with continuous rotation of syntectonic porphyroblasts.

model, it follows that the trails predominantly curve anticlockwise when viewed in the westward direction. In effect, we found the same predominance in our samples after counting the number of clockwise vs. anticlockwise trails in all vertical thin sections striking $\mathrm{N}-0, \mathrm{~N} 30, \mathrm{~N} 120$, and N150, that is, in all thin sections making a small angles with the regional stretching lineation. This resulted in 99 anticlock- wise and 27 clockwise inclusion trails viewing westward a ratio of about $4: 1$. The classic rotational interpretation of inclusion trails predicts top-to-the-north shearing from this asymmetry, which is paradoxical with respect to the widely accepted northward subduction and southward thrusting in the Armorican Massif. The non-rotational model resolves this paradox as it predicts an opposite shear sense from the 
same inclusion-trail asymmetry, consistent with top-to-thesouth thrusting (Bell and Johnson, 1989; their Figs. 16 and 17).

\subsection{Average FIA trends in five Île de Groix samples}

Hayward (1990) devised a method for determining the average orientation of porphyroblast FIAs in a sample. The method exploits the fact that sigmoidal or spiral-shaped inclusion trails, just like asymmetric folds, either exhibit an Sor Z-asymmetry in cross section (thin section) depending on the orientation of the section relative to the FIA. First, a radial set of vertical thin sections is cut from the sample with regular angular spacing around the compass. From these, the average FIA trend can be constrained to the strike interval where the inclusion-trail asymmetry observed in the different thin sections switches (e.g. Abu Sharib and Sanislav, 2013 their Fig. 2). Once the average FIA trend is known, the average FIA plunge can be constrained by cutting a new radial set of thin sections, this time about a horizontal axis oriented orthogonal to the FIA trend. The method was refined by Bell et al. (1995) to potentially allow the distinction of multiple FIA sets in a sample with different timing.

We successfully applied the method to five samples whose average FIAs are represented in Fig. 3b as pie chart symbols. FIAs were constrained to within $30^{\circ}$, but $10^{\circ}$ for sample G7 thanks to cutting two extra thin sections. The plunge direction could also be determined from the asymmetry of inclusion trails as seen in horizontal thin sections, but we did not determine plunge angles because of the large number of extra thin sections needed. No results were obtained for samples G18, G19, and G20 as these contain relatively few porphyroblasts whose inclusion trails show inconsistent asymmetries in most of their thin sections. X-ray tomography data for G20 presented in Sect. 4.6. suggest that this inconsistency is due to a mixture of two different FIA sets in these samples that could not be resolved using thin sections. Samples G3, G13, and G15 mostly contain garnets with straight inclusion trails and too few asymmetric ones to confidently apply the technique.

\subsection{Mainland samples (Pouldu schists, Tréogat formation, Central Armorican Domain)}

The "Pouldu schists" are a volcano-sedimentary unit metamorphosed in greenschist- to amphibolite-facies conditions (380-650 ${ }^{\circ} \mathrm{C}$ and 5.5-6.5 kbar; Triboulet, 1992). They crop out in a ca. $50 \mathrm{~km}$ long band along the southern coast of Brittany and contain abundant albite porphyroblasts (Fig. 2). The macroscopic cleavage in the field strikes E-W to NE-SW and generally dips steeply north or south. Horizontal thin sections of seven oriented samples of the unit show a N060 striking foliation cut by widely spaced E-W-striking dextral shear bands, likely related to the south Armorican shear zone system. In sample PO5, the N060 striking main foliation has the

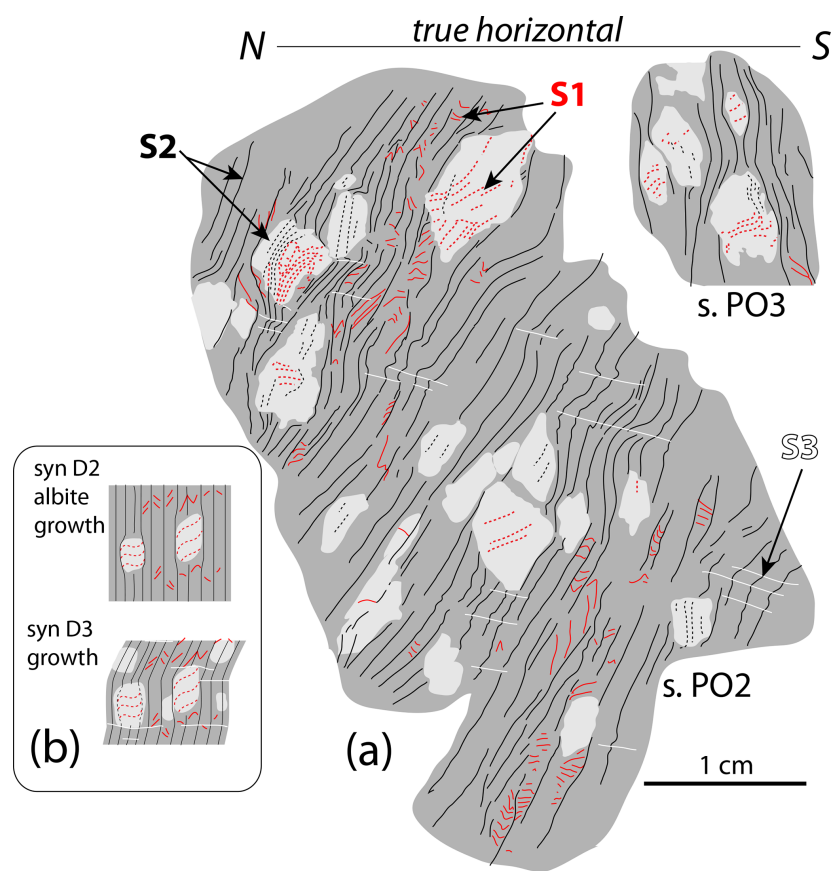

Figure 5. (a) Microstructural line drawings traced on photographs of thin sections of greenschist samples $\mathrm{PO} 2$ and PO3 containing albite porphyroblasts. Three foliations can be recognized. $\mathrm{S} 2$ corresponds to the macroscopic cleavage and crenulates an older S1. S3 corresponds to weak subhorizontal crenulations. (b) Interpretation of porphyroblast growth history. Most albite porphyroblasts form early during $\mathrm{D}_{2}$ when they overgrow $\mathrm{S} 1$. Further growth early during $\mathrm{D}_{3}$ produces additional inclusion trails of $\mathrm{S} 2$.

appearance of a narrowly spaced crenulation cleavage overprinting an older more $\mathrm{E}-\mathrm{W}$-striking foliation.

The strike of inclusion trails in albite porphyroblasts was measured in three greenschist samples of the Pouldu schists $(\mathrm{PO} 2, \mathrm{PO} 3, \mathrm{PO} 5)$ and in a fourth sample (AU1) of similar rocks cropping out in the Baye d'Audièrne (Tréogat Formation; Lucks et al., 2002). Inclusion trails consistently strike $\mathrm{E}-\mathrm{W}$ to ESE-WNW in $\mathrm{PO} 2, \mathrm{PO} 3$, and $\mathrm{PO}$, but have a larger spread in AU1 (Fig. 3b). N-S-striking vertical thin sections of $\mathrm{PO} 2$ and $\mathrm{PO} 3$ show that the main foliation ("S2" in Fig. 5a) crenulates an older "S1" included in syn- $\mathrm{D}_{2}$ porphyroblasts (Fig. 5b). Some later porphyroblast growth, probably linked to the development of weak subhorizontal crenulations ("S3" in Fig. 5), created younger inclusion trails of S2 (Fig. 5b). Nearby granites dated 330-320 Ma are deformed by S2 (Béchennec et al., 2012) and imply that this cleavage post-dates the Late Devonian to early Carboniferous metamorphism and associated polyphase deformation of Île de Groix (365-345 Ma; Bosse et al., 2005).

Two staurolite-kyanite schists from the Central Armorican Domain collected about $5 \mathrm{~km}$ NNE of Quimper were studied in horizontal thin sections only. Their inclusion trails strike broadly N060 (Fig. 3d) and might correlate with the equally N060-striking S2 in our Pouldu schist samples. The age of 
metamorphism in these rocks is broadly constrained to the period 350-320 Ma (Schulz et al., 1998).

\section{X-ray tomography of five Île de Groix samples}

\subsection{Data acquisition and processing method}

$\mathrm{X}$-ray-computed tomography (XCT) scans were acquired at the University of Granada with an Xradia 510 (Versa Zeiss) microtomographer at resolutions of $13-15 \mu \mathrm{m}$, using $140 \mathrm{kV}$ voltage and 2500-3200 projections. Four thin section blocks, each measuring $10-15 \mathrm{~cm}^{3}$, of samples $\mathrm{G} 3, \mathrm{G} 11, \mathrm{G} 12$, and G14 plus a more irregular piece of G20 of similar volume were scanned. Geographic orientation arrows made of metal wire were stuck on the samples to aid reorientation of the generated tiff image stacks such that geographic north is parallel with the $y$ axis and true vertical with the $z$ axis. Image stacks were processed with the Fiji software package (Schindelin et al., 2012). After reorientation, the spatial orientation of all straight inclusion trails or inclusion-trail segments visible in the image stacks was determined by measuring their strike and pitch angles on $x y, y z$, and $x z$ slices and fitting those angles to great circles on a stereonet. Furthermore, the curvature axes of individual sigmoidal or spiral-shaped inclusion trails (FIA) were measured in an analogous manner as the thin-section-based technique of Hayward (1990; see Sect. 3.3), and as previously done by Huddlestone-Holmes and Ketcham (2010), Aerden and Ruiz-Fuentes (2020), and Sayab et al. (2021). First, the FIA trend is constrained by interactively rotating a vertical slice through the porphyroblast and recording where the inclusion-trail curvature sense switches. Then, a horizontal slice is interactively rotated about a horizontal axis oriented normal to the previously determined FIA trend to constrain the FIA plunge.

The image stacks also allowed us to study the preferred orientation of garnet porphyroblasts as well as relatively large opaque minerals present in all five samples. The BoneJ plugin of Fiji (Doube et al., 2010) was used for this purpose. This tool enables automatic calculation of best-fit ellipsoids for a large number of "objects" in a binary (black and white) image stack. To apply this, X-ray scans were first segmented by thresholding, only leaving voxels with grey-scale values within the range corresponding to garnet crystals or opaque minerals and then binarizing the stack (i.e. setting all grey values to black). Subsequently, a size filter was applied to remove small particles and in some cases the "dilate" tool to rejoin objects belonging to the same garnet crystal that became separated during thresholding due to the presence of fractures and related alteration. In all samples except G20, welldeveloped preferred orientations of opaque minerals were detected, but not of garnets. In G20, an opposite situation was found: only well-preferred orientation of garnets was found. In the following subsections microstructural results are described for each sample and presented in stereoplots made with the program "Stereonet" of Rick Allmendinger. The original files of these stereoplots are provided in the Supplement.

\subsection{Sample G11}

G11 is a blueschist from "Amer" in the SE of the island (Fig. 3a). It contains garnet porphyroblasts as well as rectangular pseudomorphs probably after lawsonite composed of a mixture of white mica, chlorite, albite, and epidote (Cogné et al., 1966; Felix and Fransolet, 1972; Ballèvre et al., 2003). Lawsonite relics have never been found, though, and some authors have argued that the replaced mineral could have been plagioclase (Shelley and Bossière, 1999). Lawsonite is a high-pressure mineral and should have grown partially synchronous with garnet on a prograde path, whereas plagioclase is more likely to have formed during retrogression. Thus, the relative timing of the pseudomorphed mineral relative to garnet growth and inclusion trails is relevant to this question.

Inclusion trails in garnet porphyroblasts of G11 vary from simple to sigmoidal to spiral shaped, but they never curve more than about $90^{\circ}$ from the centre to the rim (Figs. 6a, $\mathrm{b}, \mathrm{c}, \mathrm{g}$ and 7). The tomographic images further revealed the presence of relatively large elongate crystals with high X-ray attenuation (higher than garnet), which in thin section were identified as magnetite, partially or completely replaced by brown-reddish goethite (Fig. 6d, h). Some of the opaques attain porphyroblastic sizes and contain scarce silicate inclusions. Best-fit ellipsoids calculated for these crystals with BoneJ (see Sect. 4.1) have long axes $(x)$ well aligned with the macroscopic mineral-stretching-intersection lineation and short axes normal to the foliation (Fig. 7).

Sigmoidal or spiral-shaped inclusion trails were measured both in the centre and in the rims, where they become sharply deflected or truncated by younger inclusion trails. The porphyroblast-rim measurements tightly define a steeply SW-dipping plane, whereas foliations within porphyroblast cores have more variable orientations between steeply NEdipping and shallowly W-dipping. The intersection lines of core and rim inclusion-trail planes agree well with 10 FIAs measured directly with the asymmetry-switch technique described in the previous section. Simple (straight) inclusion trails have variable orientations that broadly coincide with the foliations measured in porphyroblast cores and rims associated with sigmoidal and spiral-shaped trails.

The above data allow confident interpretation of the bimodal inclusion-trail strike pattern exhibited by the rose diagram for G11 in Fig. 3b as corresponding to two age sets of inclusion trails: an older set striking NNW-SSW and a younger one striking WNW-ESE. Note that the 10 individual porphyroblast FIAs determined from the X-ray scan agree well with the average FIA initially determined from the radial set of thin sections (Fig. 3b). 

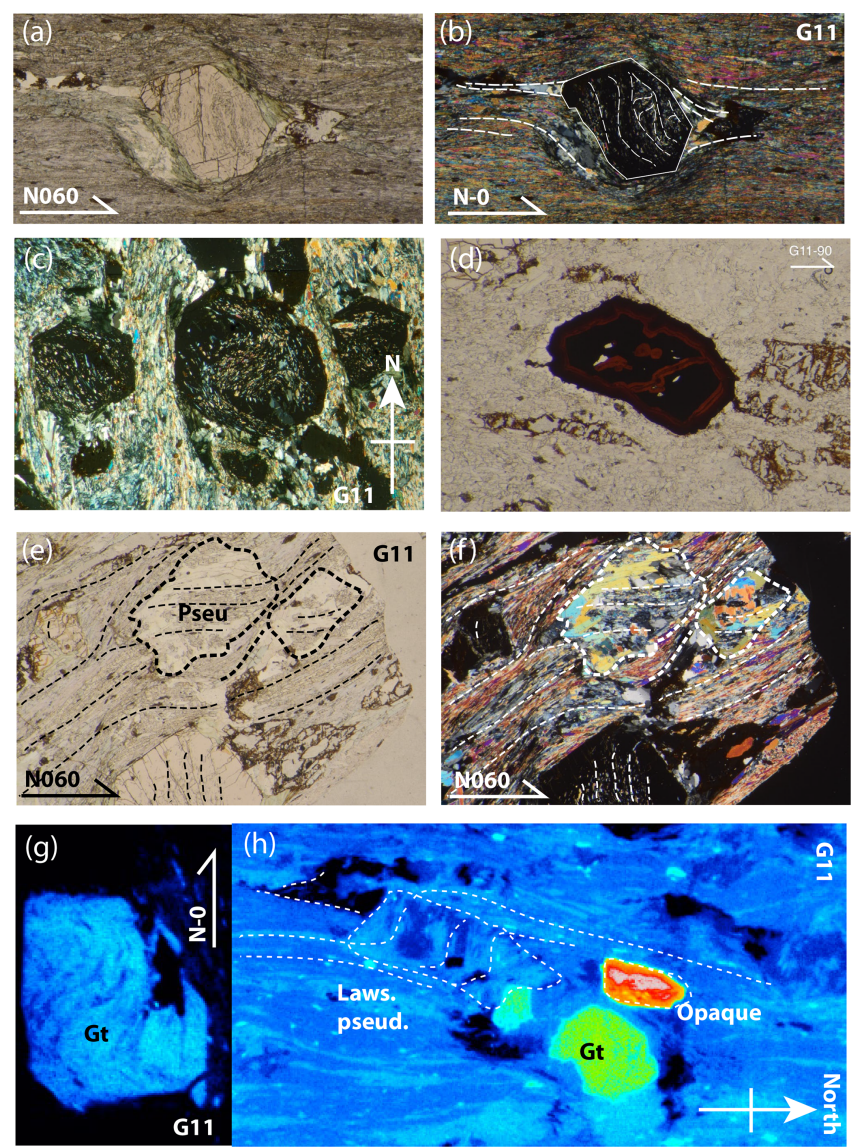

Figure 6. Photographs of G11. (a, b) Garnet porphyroblast (parallel and crossed polars) with sigmoidal trails in a N-S-striking vertical section. Barb of $\mathrm{N}$-arrow points upward. Note top-to-the-south shear sense suggested by asymmetric strain shadows consistent with a non-rotational interpretation of the inclusion trails. (c) Garnet with spiral-shaped inclusion trails with a truncation surface between the porphyroblast core and rim. (d) Opaque mineral with elongate shape replaced by goethite. (e, f) Lawsonite pseudomorphs (parallel and crossed polars) showing weakly sigmoidal inclusion trails oriented oblique to the matrix foliation. (g) Tomographic image of spiral inclusion trails garnet in G12. (h) Tomographic image of an elongate lawsonite pseudomorph, a garnet porphyroblast (Gt) and an opaque mineral.

Some of the lawsonite pseudomorphs in G11 also have visible inclusion trails in the X-ray scan (Fig. 6e, f, and h), although less finely defined as in garnets. They are straight to weakly sigmoidal, oblique to the matrix foliation, but subparallel to inclusion trails in garnet rims. The latter suggests that the pseudomorphed mineral grew synchronous with latestage garnet, and this supports that the pseudomorphed mineral was lawsonite and grew towards the end of the prograde path as concluded by Ballèvre et al. (2003). Interestingly, the curvature sense of inclusion trails in the pseudomorphs is mostly opposite to that in garnets when viewed in $\mathrm{N}-\mathrm{S}$ vertical sections. Assuming a non-rotational origin of the trails, this implies a change from top-to-the-south shearing to topto-the-north shearing that is further discussed in Sect. 6.3.

\subsection{Sample G12}

G12 is a blueschist similar to G11 from the same outcrop, but only one possible lawsonite pseudomorph could be identified in the X-ray scan, which does not show an internal fabric. The tomography of this sample reveals an early NNWSSE-striking foliation preserved within garnet porphyroblasts, overprinted by a steeply S-dipping foliation included in some garnet rims (Fig. 7). The garnet-rim foliation is in turn deflected or truncated by a subhorizontal crenulation cleavage in the matrix that is responsible for the flat-lying macroscopic cleavage. The same opaque minerals as found in G11 are present in the matrix but now also as relatively large inclusions inside garnets, often occupying a central position suggesting that the garnets nucleated on those grains. Bestfit ellipsoids for the matrix opaques demonstrate their strong elongation in the NW-SE direction parallel to the macroscopic lineation and parallel to the strike of inclusion trails in garnet.

The above data allow the correlation of the different peaks in the strike rose diagrams for G11 and G12 in Fig. 3b as (i) an early NE-SW-striking foliation preserved in the cores of spiral-shaped inclusion trails, (ii) a younger NNW-SSEstriking foliation included in the cores of sigmoidal inclusion trails with variable dip angles, and (iii) a still younger ESE-WNW foliation preserved in garnet rims and in lawsonite pseudomorphs.

\subsection{Sample G14}

G14 is another blueschist from Amer containing numerous relatively small $(1-2 \mathrm{~mm})$ garnets with straight, sigmoidal, or spiral-shaped inclusion trails. The spiral patterns exhibit significantly greater curvature (up to $180^{\circ}$; Fig. $4 \mathrm{~b}$ ) than in G11 and G12. Unfortunately, only a few garnets had visible inclusion trails in the tomography because of their very fine grain size and profuse fracturing of garnets. A few inclusion-trail planes could be measured plus five FIAs plunging steeply in different directions (Fig. 8a).

Opaque crystals are elongated in the $\mathrm{N}-\mathrm{S}$ to $\mathrm{NE}-\mathrm{SW}$ directions parallel to the modal maximum defined by 62 inclusion-trail strikes measured in two horizontal thin sections (Fig. 3b). A centimetre-scale fold outlined by an epidote-rich layer was found, whose axial plane also strikes NW-SE (Fig. 8a), hence suggesting a genetic relationship with the inclusion trails. Vertical sections oriented at a high angle to the fold axes (Fig. 8c) show refolding with subhorizontal axial planes related to the subhorizontal crenulation cleavage observed in thin sections of sample G7 (Fig. 4a). In plan view horizontal sections, the fold is transected by N-Sstriking cleavage zones and quartz lenses (Fig. 8d). 

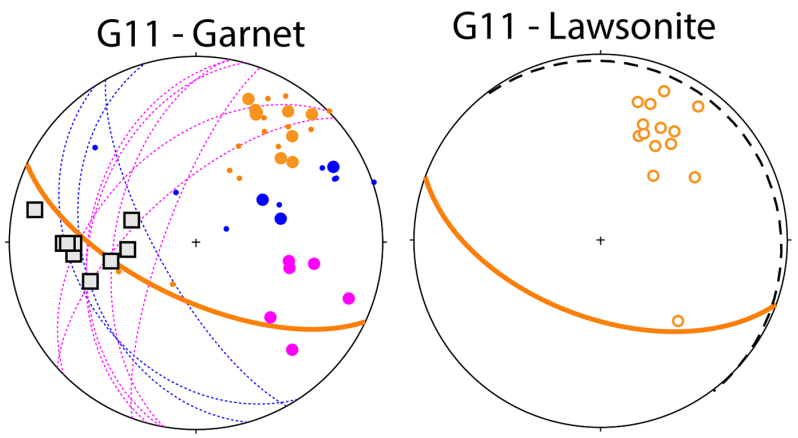

G11 - Opaque min.

G12 - Garnet
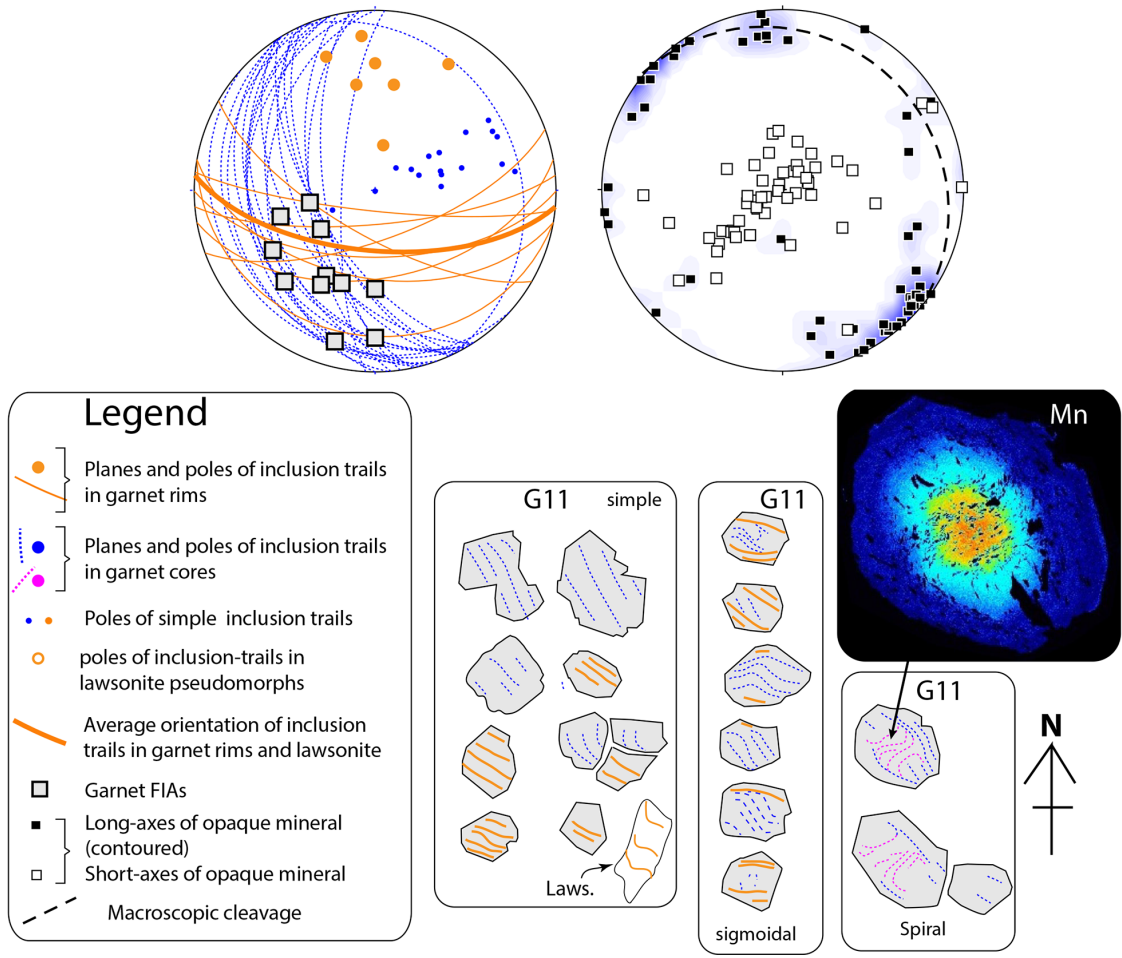

Figure 7. Stereoplots (equal angle, lower hemisphere; made with the program "Stereonet") for internal foliations and FIAs preserved within garnet crystals and lawsonite pseudomorphs in samples G11 and G12, as well as long and short axes of best-fit ellipsoids calculated for opaque minerals present in the matrix of both samples (contoured using a blue ramp). See legend and main text for detailed description of these data. The stereoplot data can be colour matched to representative oriented maps (note north arrow) of inclusion trails shown at the bottom of the figure, traced on high-resolution photographs of horizontal thin sections. A lawsonite pseudomorph (Laws.) is also drawn.

Based on their orientations, the five measured inclusiontrail planes can be correlated with the three sets already distinguished in G11 and G12. The sets are (i) an early NE-SW set responsible for the strike maximum of 62 inclusion trails measured in two horizontal thin sections of G14 (Fig. 3b), (ii) a NNW-SSE-striking set, and (iii) a late WNW-ESE set. The lack of subhorizontal internal foliations in G14 or in any other of the samples studied with X-ray tomography implies that the roughly bimodal distribution of pitch angles of inclusion trails in G7 and G14 (Fig. 4c) does not reflect a superposition of subvertical and subhorizontal foliations associated with compression-collapse cycles as shown in other metamorphic regions (Aerden and Ruiz-Fuentes, 2020, and references cited therein) but rather two sets of moderately to steeply dipping foliations with different strikes.

\subsection{Sample G3 and G7}

G3 was collected close to Fort Nosterven on the east coast of the island, about $1 \mathrm{~km}$ south of G7. Garnets in this glaucophane-epidote schist have well-developed straight and sigmoidal inclusion trails, whose strikes were measured in horizontal thin sections. The average N020 FIA trend in G7 was determined from eight vertical thin sections with different strikes. G3 was studied further with X-ray tomography, 
(b)

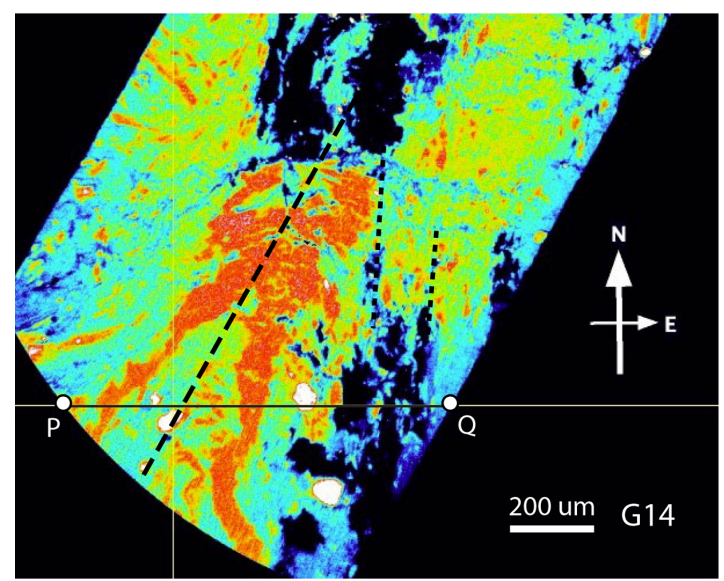

(d)

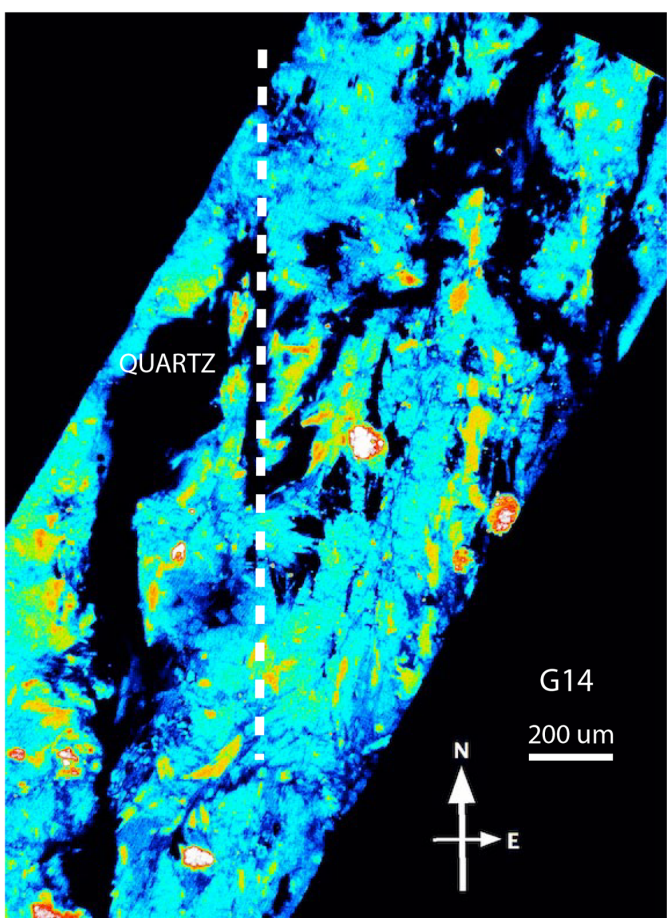

(c)

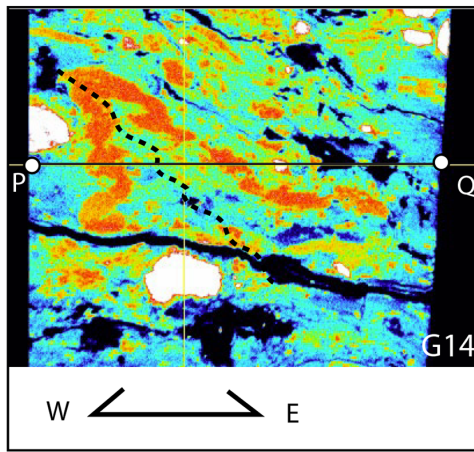

(a)

X-ray tomography data - sample G14

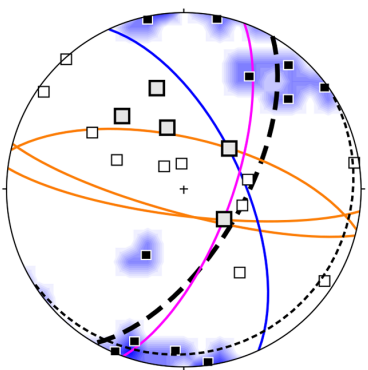

$1\}$ Inclusion trails in garnet

$\square \quad$ Garnet FIA (radial slicing technique)

- Long-axes of opaque mineral

口 (contoured)

Short-axes of opaque mineral

_- Axial plane of fold in (b) and (c)

.....- Macroscopic clevage

Figure 8. Tomographic images and microstructural data for sample G14. (a) Stereoplot for internal foliation planes, FIAs (grey boxes), long and short axes of opaque minerals, and axial plane of centimetre-scale fold. (b, c) Map and cross section views of a fold outlined by an epidote-rich layer. Its axial trace trends NNE-SSW and is transected by N-S-trending cleavage zones also visible in (d). Tomographic cross section showing refolding with subhorizontal axial planes of the fold in (b) implying a component of vertical flattening.

but its inclusion trails are poorly visible in the scan. The few that could be measured all dip steeply NW with N020 strike, parallel to the average FIA in sample G7 and a set of gently SSW-plunging folds measured by Claude Audren near G7 at Plage du Trech (1974, unpublished data; Fig. 9b). A single porphyroblast FIA was also measured, defined by sigmoidal inclusion trails that curve into a subvertical N120-striking position in the porphyroblast rim. It is most likely related to one of Audren's fold axes which has an anomalous N120 trend. Thus, this fold axis is probably younger than the main group of SSW-trending fold axes. All the above data are consistent with the orientations and relative timing of three main sets of inclusion trails and related macroscopic structures in Île de Groix, coded pink, blue, and orange in our figures.

\subsection{Sample G20}

G20 was collected near Port Lay on the central-north coast of Groix (Fig. 3a). The macroscopic cleavage dips $50^{\circ} \mathrm{NE}$ here and is associated with a subhorizontal mineral lineation 


\section{(a) Sample G3}

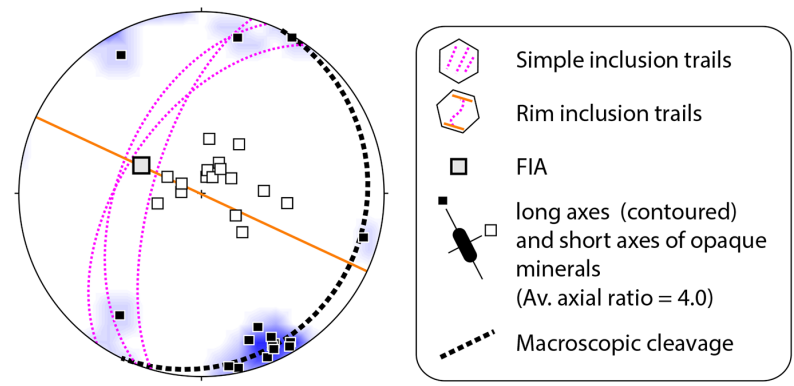

\section{(b) Field data from Plage du Trec (C. Audren 1974)}

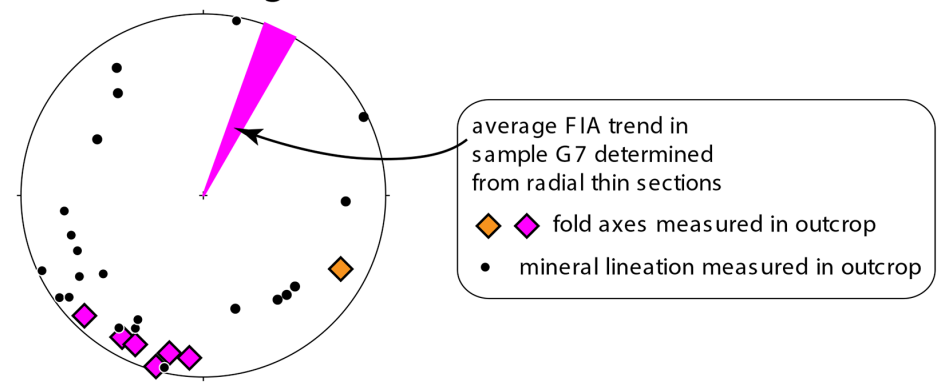

(c) Sample G20

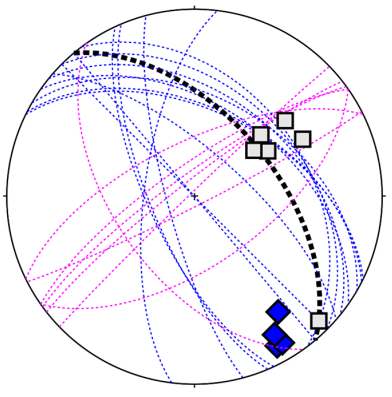

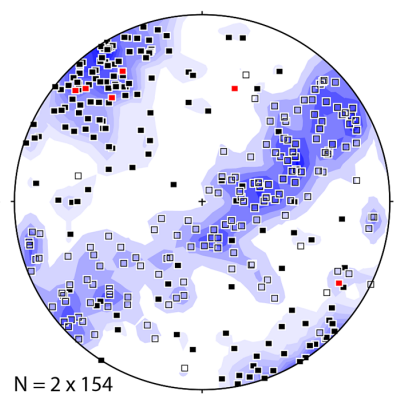

Whole-garnet incl. trails Gt-core inclusion trails FIA

$\mathrm{cm}$-scale fold axes measured in tomogr. scan

long- and short axes of al garnets (contoured) Av. axial ratio $=2.0$

long-axes of the 6 garnets whose FIA are shown in the stereoplot on the left

Macroscopic cleavage

Figure 9. (a) The 3D microstructural data for sample G3. See legend and Sect. 4.5. for detailed description of these data. (b) Field data collected by Claude Audren near sample G7 at Plage du Trech and the average FIA trend (pink pie chart) we determined for this sample from radial thin sections. The FIA trend is parallel to fold axis measurements. Note that this conflicts with progressive shearing, fold-limb rotation, and porphyroblast rotation. Stretching lineations vary significantly, reflecting polyphase deformation. (c) Microstructural data for G20. See legend and text of Sect. 4.5 for detailed description.

parallel to small-scale tight to isoclinal fold axes. Six garnet FIAs defined by sigmoidal inclusion trails were measured using X-ray tomography plus a larger number of straight inclusion trail planes. Five FIAs plunge moderately NE and are caused by the intersection of an older set of NE-SW-striking subvertical inclusion trails with a younger set of steeply NEor SW-dipping ones. Again, this allows both sets to be correlated with similarly striking inclusion trails in the other samples (Fig. 3b). The macroscopic cleavage is conspicuously parallel to a subset of the younger (NNW-SSE-striking) inclusion trails, suggesting a genetic relationship. The sixth FIA that was determined plunges shallowly SSE and prob- ably formed after the others by overgrowth of the younger inclusion trail set (blue great circles in Fig. 9c).

Abundant opaque minerals in the sample conspicuously cluster around garnet crystals, but ellipsoid best-fitting did not reveal significant preferred orientations. Axial ratios of the opaques are also much lower as in the earlier described samples (2.0 versus 4.0). Best-fit ellipsoids for garnet porphyroblasts, however, revealed their preferred elongation parallel to the lineation and fold axes and an average axial ratio of 2.1 (Fig. 9c). Aerden and Ruiz-Fuentes (2020) recently showed that garnets commonly grow elongated either parallel or perpendicular to their FIAs due to preferential nucleation in actively forming microlithon domains and growth 
controlled by the pre-existing cleavage within these domains. The six FIAs measured in G20 are all approximately normal to the maximum elongation axes (X_Gt) of their host garnets (Fig. 9c).

\section{Tectonic interpretation}

\subsection{Changes in subduction direction}

Evidence has been presented for three regionally developed sets of inclusion trails with consistent orientations that successively developed in blueschist-eclogite facies rocks of Île de Groix. All three sets probably formed on a single prograde metamorphic path reaching $18-20 \mathrm{kbar}$ and $450^{\circ} \mathrm{C}$ according to detailed petrological work (Bosse et al., 2002; Ballèvre et al., 2003). Schulz et al. (2001), however, proposed a superposition of two (Variscan) metamorphic cycles based on complex chemical zoning in amphiboles, whose relationship with the different generations of inclusion trails distinguished herein merit further research.

The three sets of inclusion trails have moderate to subvertical orientations and can be linked to three periods of crustal shortening perpendicular to their NE-SW, NNW-SSE, and WNW-ESE strikes. The earlier mentioned predominance of anti-clockwise inclusion trails observed in thin vertical thin sections that strike parallel to or at a low angle with the regional mineral lineation is likely determined by the oldest (NE-striking) and youngest (E-W-striking) inclusion-trail sets as these intersect the thin section planes at a high angle. The intermediate-age inclusion trail set strikes subparallel to the regional mineral lineation and hence can be expected to produce inconsistent curvature senses in the same thin sections (see Hayward, 1990). This may be why about $25 \%$ of all counted porphyroblasts exhibit an opposite curvature sense (i.e. clockwise).

Consequently, we interpret the oldest NE-SW-striking inclusion trails to witness a NW-directed subduction. The polarity of an intermediate subduction stage, corresponding to NNE-SSW-striking inclusion trails, remains undetermined by our data, but was probably towards the WSW according to other geological evidence (e.g. Martinez Catalán et al., 1997). The asymmetry of the youngest WNW-ESE-striking trails corresponds to the latest stages of NNE-directed subduction, followed by exhumation. Inclusion trails in the Pouldu schists have a similar orientation to those of the youngest set of Île de Groix (see Sect. 3.4). They record continued $\mathrm{N}-\mathrm{S}$ compression in the Carboniferous that still generated a late set of post-metamorphic chevron-type folds with E-W-trending axes on Île de Groix (see Sect. 6.1.).

\subsection{A gravitational spreading high-grade thrust nappe?}

The average dip of all 103 inclusion-trail planes measured with X-ray tomography in five samples from Île de Groix is $57^{\circ}\left(\sigma=21^{\circ}\right)$. The average plunge of all 33 measured FIAs is $43^{\circ}\left(\sigma=15^{\circ}\right)$. These relatively steep dips and plunges imply a limited role, if any, of intermittent gravitational collapse stages during prograde metamorphism. This is because compression-collapse cycles should generate subhorizontal FIAs formed by the intersection of alternating subvertical and subhorizontal foliations. This situation has been shown in the Appalachians, the European Alps (Bell and Bruce, 2006; their Fig. 18), and Variscan NW Iberia (Aerden, 2004; his Fig. 4b). The inclusion trails of Île de Groix, however, formed in the context of a Late Devonian subduction, before continental collision could have sufficiently thickened the crust to start off gravitational collapse phases.

A notable difference between eastern and western Île de Groix, apart from the higher metamorphic grade of the former, is the attitude of the main foliation. This is particularly clear from structural data of Cogné et al. (1966) compiled and re-plotted in Fig. 10a. Whereas in eastern Groix the main foliation dips gently east to south, in the west it dips moderately to steeply NE or SW. This difference was previously attributed to large-amplitude folding of a single main foliation with NW-SE axial planes (see Bosse et al., 2002 their Fig. 12). We alternatively propose that the flat-lying foliation in the high-grade eastern domain is more weakly developed in the lower-grade western domain, where consequently, older foliations and folds are more widely preserved as shown conceptually in Fig. 10b. This model is consistent with the extrusion and gravitational spreading of a thrust nappe over a lower-grade footwall (Fig. 10b) as famously modelled by Bucher (1956) and Merle (1989) and as proposed earlier for thrust nappes in the Montagne Noire (Aerden, 1998; Aerden and Malavieille, 1999). The model accounts for vertical shortening components associated with the flat-lying main foliation of the high-grade domain indicated by strain shadows, shear bands, and quartz fabrics all showing inconsistent shear senses (Shelley and Bossière, 1999) and by steeply dipping foliations preserved within porphyroblasts documented here.

Detailed field observations of Cogné et al. (1966) and Boudier and Nicolas (1976) at Vallon du Lavoir (central south coast; Fig. 3a) also corroborate an important role of vertical shortening in the lower-grade western domain. Both works describe a decametre-scale upright anticline at this location overprinted by a horizontal crenulation cleavage and related metre-scale refolding (Fig. 10c and d). This geometry is directly comparable with the centimetre-scale vertically flattened fold found in sample G14 (Fig. 8c).

Samples G18, G19, and G20 come from the same outcrop near Port Lay (Fig. 3a) where the main cleavage dips steeply $\left(50^{\circ}\right) \mathrm{NE}$, despite still belonging to the high-grade domain and located close to the inferred basal thrust. The first explanation that comes to mind is that the foliation was originally flat lying but was later steepened by folding. However, the following observations suggest otherwise. Firstly, the foliation is parallel to and partially continuous with a set of NNW-SSE-striking inclusion trails in G20 (Fig. 9c - blue 

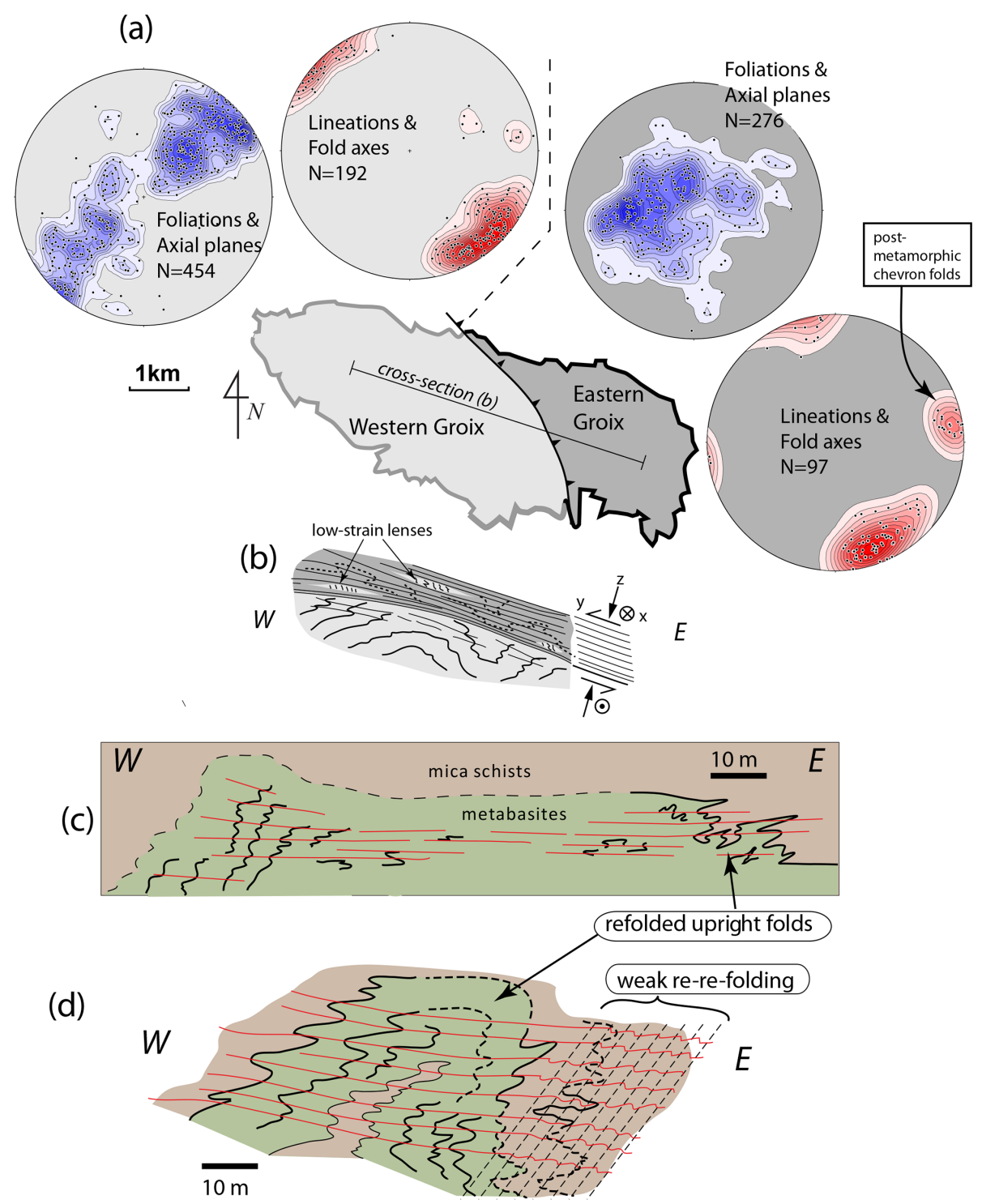

Figure 10. (a) Main foliation and lineation data from Cogné et al. (1966) re-plotted in equal-area, lower-hemisphere stereoplots for highergrade eastern Groix and lower-grade western Groix. The high-grade domain has a gently E-S-dipping foliation. The lower-grade area has moderately to steeply SW- and NE-dipping foliations. The original plot files are included in the Supplement. (b) Proposed interpretation of the structural relationship between both domains separated by a thrust cutting pre-existing folds. (c) Re-drafted field sketch of Boudier and Nicolas (1976; their Fig. 2) of an outcrop at Vallon du Lavoir showing upright folds overprinted by a subhorizontal crenulation cleavage and associated refolding. (d) Re-drafted field sketch of Cogné et al. (1966; their Fig. 5) at Vallon du Lavoir, which we interpret as a tight anticline overprinted by a horizontal cleavage, in turn overprinted by a SW-dipping crenulation cleavage. The dashed line has been added .

great circles). In contrast, the flat-lying transposition cleavage at Amer (samples G11, G12, and G14) formed after a younger set of WNW-ESE-striking inclusion trails (Fig. 7 orange great circles). Thus, the main foliations at both locations do not appear to be the same generation. Secondly, the main foliation in G20 is sharply deflected towards the horizontal at matrix-garnet boundaries, suggesting the sample was affected by vertical shortening, although only weakly. This leads us to interpret the studied outcrop at Port Lay as forming part of a low-strain lens (Fig. 10b).

\section{Discussion}

\subsection{Inclusion trail sets vs. folding sequences in the field}

Cogné et al. (1966) distinguished three deformation phases. Their first phase corresponds to tight to isoclinal folds (called "fundamental folds") with NW-SE to N-S trends. The second phase caused refolding of the fundamental folds associated with a SW-dipping crenulation cleavage striking N130140 as shown in their field sketch (Fig. 10d). A third set 
of E-W-trending chevron-type folds were considered postmetamorphic. The authors describe variable relationships between the mineral lineation (defined by glaucophane and epidote) and fold axes as being commonly parallel to each other and apparently coeval but locally oblique indicating a younger age of the folding and still elsewhere associated with the second-phase folds. In the latter case, two sets of oblique glaucophane lineations were reported (their Fig. 12, p. 70).

Boudier and Nicolas (1976) distinguished four deformation phases $\left(D_{1}-D_{4}\right)$, the youngest of which corresponds to the third-phase (post-metamorphic) structures of Cogné et al. (1966). $\mathrm{D}_{1}$ refers to the mineral lineation $\left(\mathrm{L}_{1}\right)$, and $\mathrm{D}_{2}$ and $\mathrm{D}_{3}$ refer to NNW-SSE-trending folds that partially reoriented $\mathrm{L}_{1}$. Orientation data of these authors show a good match with the strike directions of our successive inclusion trail sets (Fig. 11b, c). However, our new microstructures indicate an opposite relative timing of N165- versus N120-trending fabrics in better agreement with Cogné et al. (1966) and Quinquis and Choukroune (1981). Additional evidence for younger N120 structures was found in a sketch by Claude Audren in 1974 (unpublished as far as we know) kept at the "Maison de la Reserve Naturelle Le Bail" on Île de Groix. The sketch (redrafted in Fig. 11a) depicts folding of a N160-trending lineation around the hinge of a N120 fold.

\subsection{Formation mechanism of sheath folds}

Based on a detailed study of quartz fabrics in 57 samples, Shelley and Bossière (1999) concluded that most folds of Île de Groix island nucleated with their axes immediately parallel to the maximum stretching direction $(x)$, instead of first parallel to the $y$ axes and then rotating towards $x$ during progressive shearing (see Cobbold and Quinquis, 1980; Quinquis and Choukroune, 1981). However, they still interpreted a single kinematic frame with a component of shortening parallel to the intermediate strain axes $(y)$. The polyphase character of the main (composite) foliation and lineation demonstrated herein places the significance of fold-axis-parallel stretching and the origin of sheath folds in a different light. Fold axes could have nucleated with their axes parallel to $x$ due to vertical shortening of vertical foliations and upright folds whose axes were already subparallel to $x$ (Fig. 12). Likewise, non-cylindrical folds and sheath folds may have formed by vertical flattening of precursor folds with subvertical axial planes but steeply plunging or subvertical axes (Fig. 12). Thus, depending on the geometry of the precursor folds, new folds nucleated either with straight axes parallel to $x$ or with strongly curved axes oblique to $x$. This model agrees well with the detailed analysis of Audren and Triboulet (1993) of a sheath from Groix in which they concluded that the fold started to form towards the end of the prograde path but developed further during the retrogression.

\subsection{Inclusion trail data vs. shear bands}

Predominantly clockwise curvature of inclusion trails in lawsonite pseudomorphs studied in sample G11 versus anticlockwise in garnets suggests a change from top-to-thesouth to top-to-the-north shearing, provided that the inclusion trails formed by overgrowth of crenulations (the nonrotation model). Interestingly, Philippon et al. (2009) deduced a similar switch in regional-tectonic transport from two sets of shear bands studied along the south coast of the island. They claimed that high-grade rocks conserving well-shaped lawsonite pseudomorphs only contain top-tothe-south shear bands, whereas rocks lacking such pseudomorphs also contain top-to-the-north criteria or exclusively so. Based on this, it was concluded that prograde metamorphism was associated with top-to-the-south shearing and was followed by top-to-the-north shearing, retrogression, and partial destruction of pseudomorphs. However, our lawsonite-bearing sample G11 cast doubts on this model as it exhibits mainly top-to-the-north shear-sense criteria in $\mathrm{N}$ $\mathrm{S}$ sections (cross Fig. 13) despite coming from a location where, according to Fig. 6 of Philippon et al. (2009), topto-the-south criteria should be found. Moreover, the authors excluded from their statistical analysis shear bands occurring close to or within inverted limbs of tight to isoclinal folds, perhaps because they concluded that the folding postdates the shear bands and might have completely overturned them. In the absence of less ambiguous evidence for different metamorphic conditions of both shear-band sets and for their timing relative to folding, we consider a synchronous origin of opposite shear-band sets in bulk coaxial deformation accompanied by retrogression more likely following Shelley and Bossière (1999). The local predominance of one set may simply reflect the partitioning of bulk coaxial deformation in zones with opposite shear senses.

\subsection{Comparison with inclusion-trail data from NW Iberia}

Figure 14 compares the inclusion-trail and field data presented herein from southern Brittany with that of Aerden (2004) for the "Basal Unit" of the allochthonous complexes of NW Iberia. This unit is composed of orthogneisses and high-pressure mica schists retrogressed to greenschist facies and represents the subducted margin of Gondwana (Arenas et al., 1995; Martínez-Catalán et al., 1996; Fig. 2a). Thus, it occupies a similar structural position as the Pouldu schists below an ophiolitic unit. Three sets of inclusion trails striking E-W, NE-SW, and NNW-SSE were distinguished in this unit preserved within plagioclase and garnet porphyroblasts. The oldest of these has an E-W trend and can be linked to a high-pressure event dated 370-360 Ma ( $\mathrm{Li}$ and Massonne, 2017), hence synchronous with prograde metamorphism in Île de Groix (Bosse et al., 2005). The two younger internal 

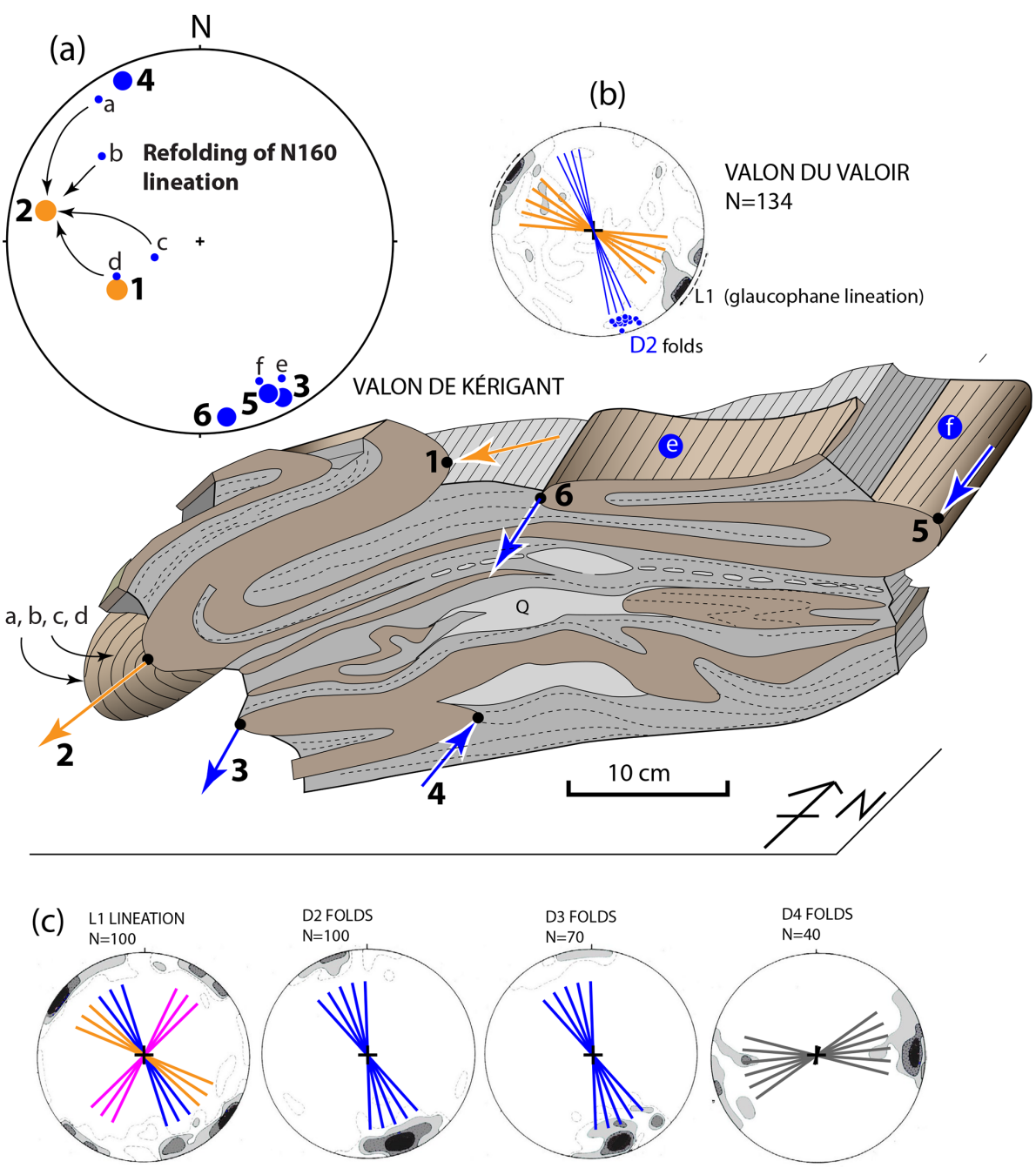

Figure 11. (a) Accurately re-drawn sketch by Claude Audren (1974; unpublished as far as we know) of isoclinal folds at Vallon de Kérigant and corresponding structural data. Refolding of a N165-trending lineation around the nose of a N120-trending fold is indicated. (b) Lineations $\left(\mathrm{L}_{1}\right)$ measured at nearby location Vallon du Lavoir by Boudier and Nicolas (1976) showing a N120 trend maximum of $\mathrm{L}_{1}$ (yellow trend lines) oblique to B2 fold axes (blue trend lines). (c) Structural data from the same authors collected across the island. Note the bimodal pattern of $\mathrm{L}_{1}$ reflecting the strikes of the three sets of inclusion trails distinguished in Figs. 3, 6, 8, and 9.

foliations sets formed at lower pressures, and their age is only loosely constrained to pre-320 Ma.

The palaeogeographic reconstruction of Fig. 14a fits the northern continental margin of Iberia to the conjugate margin of south Brittany, which requires $20^{\circ}$ clockwise backrotation of Iberia. This amount of back-rotation produces a remarkably good match of inclusion-trail orientations in both regions, yet raises a relative timing problem. Aerden (2004) interpreted that NNW-SSE-striking inclusion trails in the Basal Unit (marked blue in Fig. 14a) post-date the E-W ones marked yellow, which is opposite to what has been concluded in this paper for Île de Groix. Since the relative timing of Aerden (2004) was based on only one sample (sample 1 - Fig. 14a), we believe there is scope to further test this chronology by studying new samples with now available 3D techniques. The timing of NE-SW-striking inclusion trails in NW Iberia (marked red in Fig. 14a) is based on more abundant microstructural and field criteria, ruling out a correlation with the also NW-SE-striking but much older inclusion-trail set in Île de Groix. A correlation is possible, though, with the internal foliations of the two samples from the Central Armorican Domain and the crenulation cleavages observed in some of the Pouldu schist samples (Fig. 3c and d).

In order to further assess the goodness of fit of the microstructural data in both regions, we applied a statistical test to all yellow and blue inclusion-trail trend lines in Fig. $14 \mathrm{a}$ considered for $5^{\circ}$ increments of Iberia back-rotation between 0 and $40^{\circ}$. Watson's $\mathrm{U}^{2}$ test for uniformity of two samples of circular data is appropriate here (Mardia et al. 2009; Agostinelli and Lund, 2017). The results of this test applied 


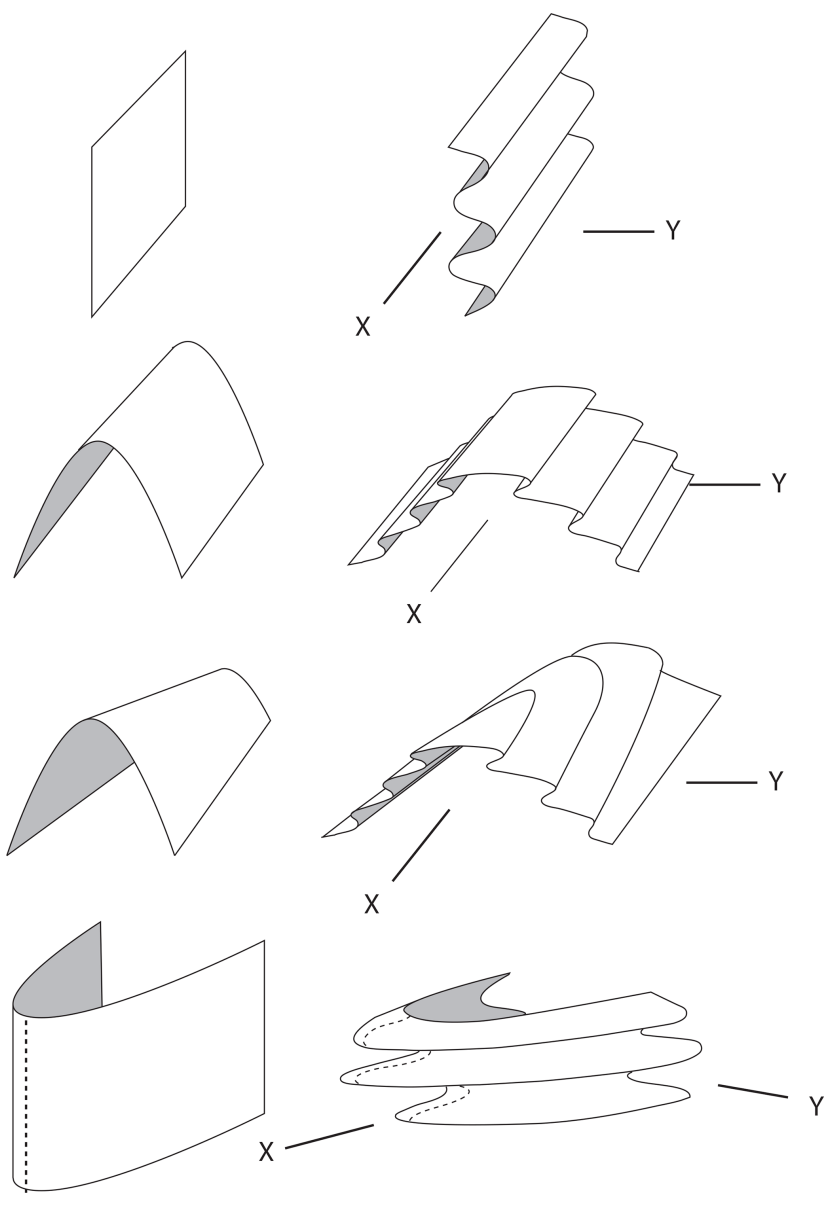

Figure 12. Conceptual models showing how vertical shortening and horizontal stretching can have produced highly variable fold geometries depending on the original orientations of pre-existing folds. Note how strongly curved fold axes can form without need of extremely large shear trains. Adding a (horizontal) shearing component in the direction of $x$ and/or $y$ can be expected to have further modified the fold-interference patterns.

to our data (Fig. 14b) show that back rotations of $0-15^{\circ}$ produce roughly equally good fits, but that above $15^{\circ}$ the degree of fit worsens rapidly. Significantly, this supports recent plate kinematic reconstructions of the North Atlantic involving only $10-20^{\circ}$ anticlockwise rotation of Iberia (Jammes, et al., 2009; Nirrengarten et al., 2018; Barnett-Moore et al., 2018).

We checked the curvature sense of rotational inclusion trails in seven of the Aerden (2004) samples associated with the subduction related E-W- to NW-SE-trending FIAs (marked yellow in Fig. 14a). In samples 3, 4, 10, 14, and 20, inclusion trails curve anticlockwise viewing west; in samples 2 and 19 they curve clockwise. The larger number of anticlockwise trails is the same as observed in Île de Groix, although we realize that this coincidence needs to be further tested.
SOUTH $\angle$ true horizontal $\quad \backslash$ NORTH

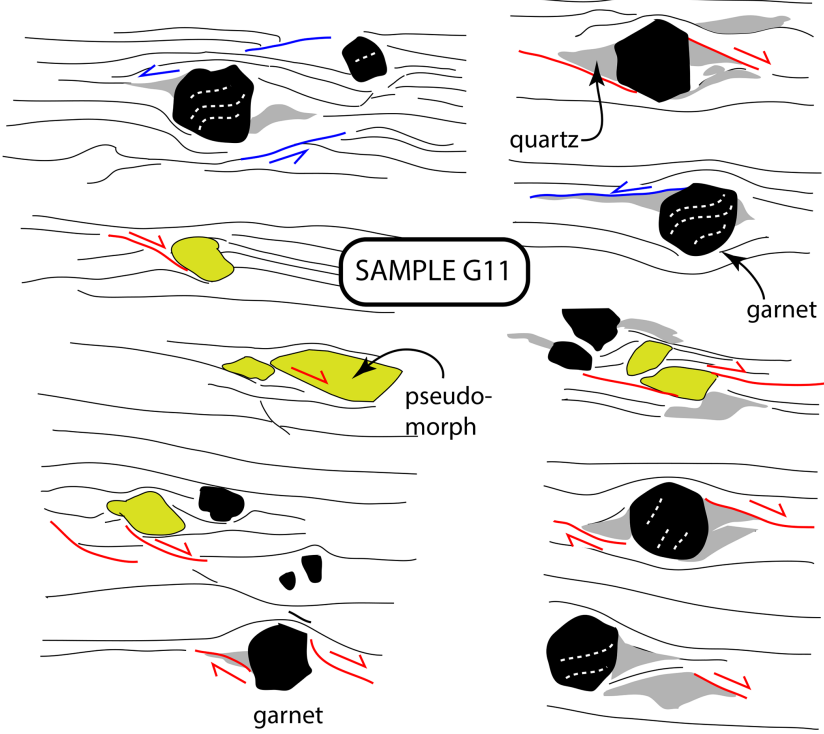

Figure 13. Asymmetric strain shadows and shear bands indicating mainly top-to-the-north but some top-to-the south shearing as well in a N-S-striking vertical section of G11. These criteria are associated with a horizontal transposition cleavage that post-dates garnet porphyroblasts. Note anticlockwise curvature sense of inclusion trails. The FIAs of these garnets plunge $45^{\circ}$ west (see Fig. 7) highly oblique to the (horizontal) matrix foliation.

\section{Conclusions}

1. Garnet and pseudomorphed lawsonite porphyroblasts in blueschist-eclogite facies rocks of Île de Groix preserve a succession of three sets of steeply dipping inclusion trails striking NW-SE, NNW-SSE, and WNW-ESE. They are interpreted to record three episodes of differently oriented compression orthogonal to these strikes during subduction-related metamorphism dated 365$355 \mathrm{Ma}$ (Bosse et al., 2005).

2. The consistency of inclusion-trail orientations across Groix island implies limited porphyroblast rotation and hence an origin of sigmoid and spiral inclusion trails by overgrowth of successive crenulation cleavages (e.g. Bell et al., 1986; Aerden, 1995; Stallard and Hickey, 2001; Aerden and Ruiz-Fuentes, 2020) rather than progressive shearing and porphyroblast rotation. This reinterpretation reconciles a previous conflict between the dominant curvature sense of inclusion trails on Île de Groix and north- or northwestward-directed subduction of Gondwana under Armorica dictated by the general tectono-metamorphic zonation of the Ibero-Armorican Arc.

3. Porphyroblast growth was followed by the development of a subhorizontal crenulation cleavage accompanying 


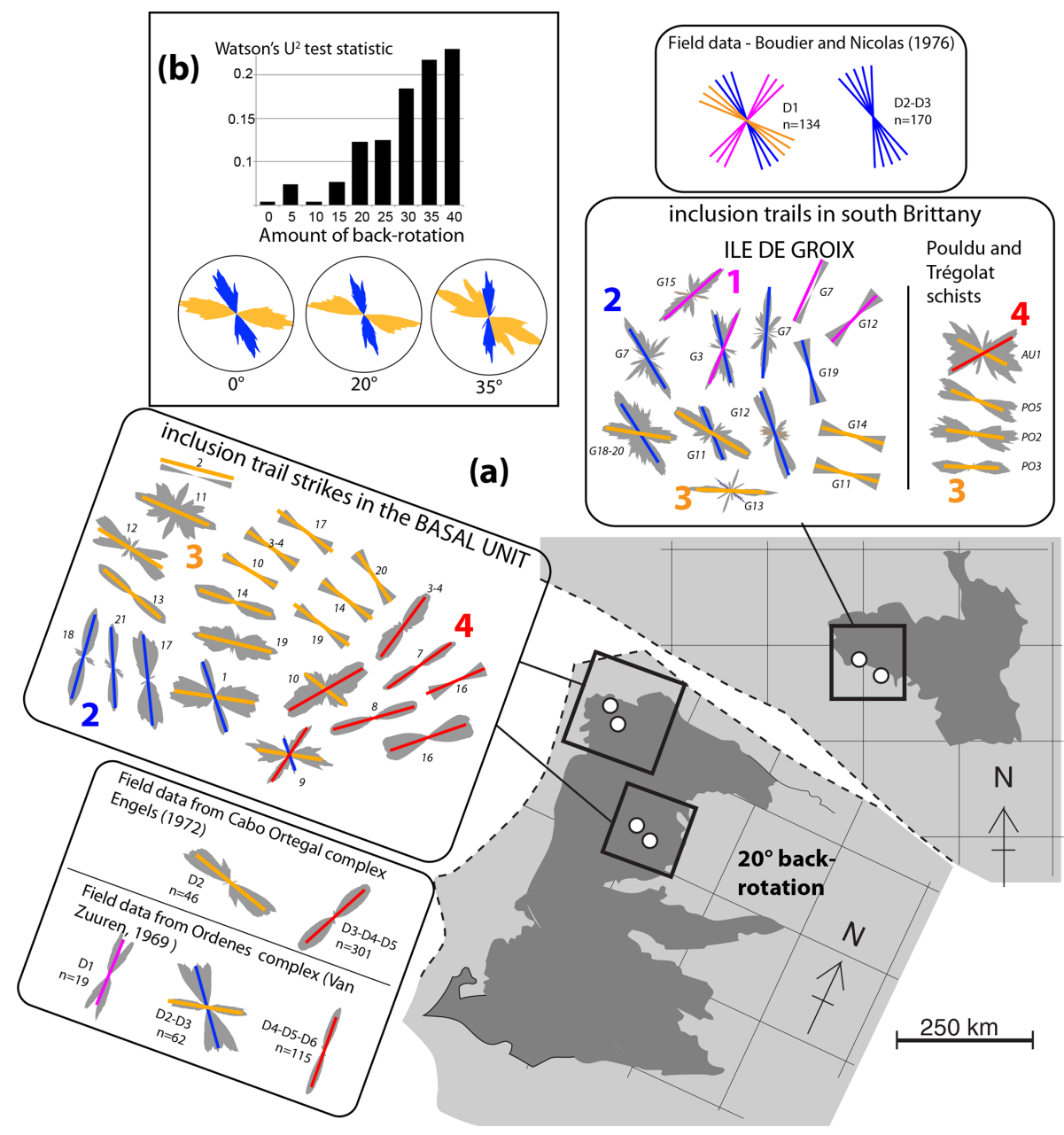

Figure 14. (a) Inclusion trail and strike measures for the present study and those of Aerden (2004) for 18 samples of the "Basal Unit" of the allochthonous complexes of NW Iberia. The microstructures are correlated as four sets marked pink, blue, yellow, and red from older to younger. Field data from Boudier and Nicolas (1976), Engels (1972), and van Zuuren (1969) correlated with the inclusion trails also show a good match. (b)The three rose diagrams plot all blue and yellow inclusion-trail trend lines shown in (a) for 0,20 , and $35^{\circ}$ Iberia back rotation. The small bar graph gives the test statistic of Watson's $\mathrm{U}^{2}$ two-sample test for $5^{\circ}$ increments of Iberia back rotation. The lower the test statistic, the better the fit. The analysis suggests no more than $15^{\circ}$ relative rotation between NW Iberia and Armorica.

retrogression and exhumation (Shelley and Bossière, 1999) and dated 355-345 Ma (Bosse et al., 2005). This foliation fully transposed earlier steeply dipping fabrics preserved within porphyroblasts and produced inconsistent (opposite) shear-sense criteria, such as asymmetric strain shadows, shear bands, and quartz $c$-axis fabrics. Together with centimetre- to decametre-scale foldinterference patterns, this indicates vertical sub-coaxial shortening, which we tentatively relate to gravitational spreading of a thrust nappe during continuous plate convergence.

4. Fold axis parallel stretching and variable fold geometries ranging from cylindrical to sheath-like did not result from progressive shearing parallel to a single foliation (see Cobbold and Quinquis, 1980) but from vertical shortening and horizontal shearing of pre-existing folds with subvertical axial planes.

5. Inclusion trails studied in four greenschist samples from the Pouldu schists (part of the footwall of the Île-deGroix ophiolitic nappe) strike WNW-ESE, subparallel to the youngest set of inclusion trails on Groix island. They record continued $\mathrm{N}-\mathrm{S}$ compression in the Carboniferous possibly synchronous with gravitational spreading in the ophiolitic hanging wall, but also afterwards when a late set of E-W-trending chevron-style folds developed on Groix island.

6. The three sets of inclusion trails documented in southern Brittany can be tentatively matched to three similar sets in NW Iberia (Aerden, 2004) in a palaeogeographic reconstruction that places the northern margin of Iberia 
back against the conjugate margin of southern Brittany. The alignment of inclusion trails in this reconstruction suggests that Iberia experienced not more than $15^{\circ}$ anticlockwise rotation during the opening of the Gulf of Biscay.

Supplement. The supplement related to this article is available online at: https://doi.org/10.5194/se-12-971-2021-supplement.

Author contributions. DA and AF collected the samples. The laboratory work was carried out by DA assisted by ARF for the acquisition and study of X-ray tomographies and by MS for the preparation and study of radial sets of thin sections. The paper was written by the first author, but all authors contributed to the presented interpretation of data.

Competing interests. The authors declare that they have no conflict of interest.

Special issue statement. This article is part of the special issue "The Iberian Massif in the frame of the European Variscan Belt". It is not associated with a conference.

Acknowledgements. The first author wishes to thank José Ramón Martínez Catalán for his guidance and friendship during a postdoc in Salamanca (1996-1999). We thank Michel Ballèvre for helping us obtain permission from the Préfecture du Morbihan to collect samples on Île de Groix and for suggesting we include the Pouldu schists in our study. Île de Groix national park guide Catherine Robert (and her dog) provided Domingo Aerden with helpful information and pleasant company during fieldwork. We thank Fátima Linares-Ordoñez for X-ray scanning our samples and Bernhardt Schulz for clarifying various aspects about the petrology of the study area. The authors are very grateful to the two anonymous reviewers, who provided constructive comments, and the handling editors of Solid Earth, Ícaro Dias da Silva and Federico Rossetti.

Financial support. The research was supported by Spanish government project CGL2016-80687-R AEI/FEDER and projects RNM148, P18-RT-3275 and B-RNM-301-UGR18 of the Andalusia Autonomous Government.

Review statement. This paper was edited by Ícaro Dias da Silva and reviewed by two anonymous referees.

\section{References}

Abu Sharib, A. S. A. A. and Bell, T. H.: Radical changes in bulk shortening directions during orogenesis: Significance for pro- gressive development of regional folds and thrusts, Precambrian Res., 188, 1-20, 2011.

Abu Sharib, A. S. A. A. and Sanislav, I. V.: Polymetamorphism accompanied switching in horizontal shortening during Isan Orogeny: example from the Eastern Fold Belt, Mount Isa Inlier, Australia, Tectonophysics, 587, 146-167, 2013.

Aerden, D. G. A. M.: Kinematics of orogenic collapse in the Variscan Pyrenees deduced from microstructures in porphyroblastic rocks from the Lys-Caillaouas massif, Tectonophysics, 238, 139-160, https://doi.org/10.1016/0040-1951(94)90053-1, 1994.

Aerden, D. G. A. M.: Porphyroblast non-rotation during crustal extension in the Variscan Pyrenees, J. Struct. Geol., 17, 709-726, 1995.

Aerden, D. G. A. M.: Tectonic evolution of the Montagne Noire and a possible orogenic model for syn-collisional exhumation of deep rocks, Hercynian belt, France, Tectonics, 17, 62-79, 1998.

Aerden, D. G. A. M.: Correlating deformations in the Iberian Massif (Variscan belt) using porphyroblasts; implications for the development of the Ibero-Armorican Arc, J. Struct. Geol., 26, 177196, 2004.

Aerden, D. G. A. M., Bell, T. H., Puga, E., Sayab, M., Lozano, J. A., and Díaz de Federico, A.: Multi-stage mountain building vs. Relative plate motions in the Betic Cordillera deduced from integrated microstructural and petrological analysis of porphyroblast inclusion trails, Tectonophysics, 587, 188-206, 2013.

Aerden, D. G. A. M. and Malavieille, J.: Origin of a large-scale fold nappe in the Montagne Noire, Variscan belt, France, J. Struct. Geol., 21, 1321-1333, 1999.

Aerden, D. G. A. M. and Sayab, M.: Probing the prodigious strain fringes from Lourdes, J. Struct. Geol., 105, 88-106, https://doi.org/10.1016/j.jsg.2017.11.001, 2017.

Aerden, D. G. A. M. and Ruiz-Fuentes, A.: X-ray computed microtomography of spiral garnets: A new test of how they form, J. Struct. Geol., 136, 104054 https://doi.org/10.1016/j.jsg.2020.104054, 2020.

Agostinelli, C. and Lund, U.: R package "circular": Circular Statistics (version 0.4-93), available at: https://r-forge.r-project.org/ projects/circular/, 2017.

Ali, A.: The tectono-metamorphic evolution of the Balcooma Metamorphic Group, north-eastern Australia: a multidisciplinary approach, J. Metamorph. Geol., 28, 397-422, https://doi.org/10.1111/j.1525-1314.2010.00871.x, 2010.

Arenas, R., Rubio Pascual, F., Díaz García, F., and Martínez Catalán, J. R.: High-pressure micro-inclusions and development of an inverted metamorphic gradient in the Santiago Schists (Ordenes Complex, NW Iberian Massif, Spain): evidence of subduction and syncollisional decompression, J. Metamorph. Geol., 13, 141-164, 1995.

Arenas, R., Sanchez Martinez, S., Diez Fernandez, R., Gerdes, A., Abati, J., Fernandez-Suarez, J., Andonaegui, P., Cuadra, P. G., Carmona, A. L., Albert, R., Fuenlabrada, J. M., and Rubio Pascual, F. J.: Allochthonous terrains involved in the Variscan suture of NW Iberia: A review of their origin and tectonothermal evolution, Earth-Sci. Rev., 161, 140-178, 2016.

Audren, C. and Triboulet, C.: Les chemins pression-température enregistrés au cours de la formation de plis non-cylindriques dans les schistes bleus de l'Ile de Groix (Bretagne méridionale, 
France), Comptes Rendus de l'Académie des Sciences de Paris (II), 317, 259-265, 1993.

Audren, C., Triboulet, C., Chauris, L., Lefort, J. P., Vigneresse, J. L., Audrain, J., Thiéblemont, D., Goyallon, J., Jégouzo, P., Guennoc, P., Augris, C., and Carn, A.: Notice explicative de la feuille Ile de Groix à 1/25 000 (carte géologique), BRGM, Orléans, 1993.

Azor, A., Rubatto, D., Simancas, J. F., González Lodeiro, F., Martínez Poyatos, D., MartínParra, L. M., and Matas, J.: Rheic Ocean ophiolitic remnants in southern Iberia questioned by SHRIMP U-Pb zircon ages on the Beja-Acebuches amphibolites, Tectonics, 27, TC5006, 2008.

Ballevre, M., Pitra, P., and Bohn, M.: Lawsonite growth in the epidote blueschists from the Ile de Groix (Armorican Massif, France): a potential geobarometer, J. Metamorph. Geol., 21, 723735, 2003

Ballèvre, M., Bosse V., Ducassou, C., and Pitra, P.: Palaeozoic history of the Armorican Massif: Models for the tectonic evolution of the suture zones, C. R. Geosci., 341, 174-201, 2009.

Ballevre, M., Bosse, V., Dabard, M. P., Ducassou, C., Fourcade, S., Paquette, J. L., Peucat, J. J., and Pitra, P.: Histoire Géologique du massif Armoricain: Actualitée de la recherche. Bulletin de la Sociétée Géologique et Minéralogique de Bretagne, Société géologique et minéralogique de Bretagne, 10-11, 5-96, 2015.

Barnett-Moore, N., Müller, D. R., Williams, S., Skogseid, J., and Seton, M.: A reconstruction of the North Atlantic since the earliest Jurassic, Basin Research 30 (Suppl. 1), 160-185, https://doi.org/10.1111/bre.12214, 2018.

Béchennec, F., Hallégouët, B., Thiéblemont, D., and Thinon, I.: Notice explicative, Carte géol. France (1/50 000), feuille Lorient (383), BRGM, Orléans, 206 pp., 2012.

Bell, T. H.: Deformation partitioning and porphyroblast rotation in metamorphic rocks: A radical reinterpretation, J. Metamorph. Geol., 3, 109-118, 1985.

Bell, T. H. and Bruce, M. D.: The internal inclusion trail geometries preserved within a first phase of porphyroblast growth, J. Struct. Geol., 28, 236-252, 2006.

Bell, T. H. and Johnson, S. E.: Porphyroblast inclusion trails: the key to orogenesis, J. Metamorph. Geol., 7, 279-310, 1989.

Bell, T. H. and Sapkota, J.: Episodic gravitational collapse and migration of the mountain chain during orogenic roll-on in the Himalayas, J. Metamorph. Geol., 30, 651-666, 2012.

Bell, T. H. and Welch, P. W.: Prolonged Acadian Orogenesis: revelations from foliation intersection axis (FIA) controlled monazite dating of foliations in porphyroblasts and matrix, Am. J. Sci., 302, 549-581, 2002.

Bell, T. H., Rubenach, M. J., and Flemming, P. D.: Porphyroblast nucleation, growth and dissolution in regional metamorphic rocks as a function of deformation partitioning during foliation development, J. Metamorph. Geol., 4, 37-67, 1986.

Bell, T. H., Johnson, S. E., Davis, B., Forde, A., Hayward, N., and Wilkins, C.: Porphyroblast inclusion-trail orientation data: eppure non son girate! J. Metamorph. Geol., 10, 295-307, 1992.

Bell, T. H., Forde, A., and Wang, J.: A new indicator of movement direction during orogenesis - measurement technique and application to the Alps, Terra Nova, 7, 500-508, 1995.

Bell, T. H., Hickey, K. A., and Upton, G. J. G.: Distinguishing and correlating multiple phases of metamorphism accross a multiply deformed region using the axes of spiral, staircase, and sig- moidally curved inclusion trails in garnet, J. Metamorph. Geol., 16, 767-794, 1998.

Bosse, V., Ballèvre, M., and Vidal, O.: Ductile thrusting recorded by the garnet isograd from blueschist-facies metapelites of the Île de Groix, Armorican Massif, France, J. Petrol., 43, 485-510, 2002.

Bosse, V., Féraud, G., Ballèvrec, M., Peucatc, J. J., and Corsini, M.: $\mathrm{Rb}-\mathrm{Sr}$ and ${ }^{40} \mathrm{Ar} /{ }^{39} \mathrm{Ar}$ ages in blueschists from the Ile de Groix (Armorican Massif, France): Implications for closure mechanisms in isotopic systems, Chem. Geol., 220, 21-45, 2005.

Boudier, F. and Nicolas, A.: Interprétation nouvelle des relations entre tectonique et métamorphisme dans l'île de Groix (Bretagne), B. Soc. Géol. France, S7-XVIII, 135-144, 1976.

Bucher, H.: Role of gravity in orogenesis, Bull. Geol. Soc. Am., 67, 1295-1318, 1956.

Cannat, M.: Quartz microstructures and fabrics in the island of Groix (Brittany, France), J. Struct. Geol., 7, 555-562, 1985.

Cobbold, P. R. and Quinquis, H.: Development of sheath folds in shear regimes, J. Struct. Geol., 2, 119-126, 1980.

Cogné J., Daniel, J., and Ruhland, M.: L'Ile de Groix. Etude structurale d'une série métamorphique à glaucophane en Bretagne méridionale, in: Bulletin du Service de la carte géologique d'Alsace et de Lorraine, 19-1, 41-96, https://doi.org/10.3406/sgeol.1966.1298, 1966.

Díaz García, F., Arenas, R., Martínez Catalán, J. R., González del Tánago, J., and Dunning, G. R.: Tectonic evolution of the Careón ophiolite (northwest Spain): A remnant of the oceanic lithosphere in the Variscan Belt, J. Geol., 107, 587-605, 1999.

Doube, M., Kłosowski, M. M., Arganda-Carreras, I., Cordeliéres, F., Dougherty, R. P., Jackson, J., Schmid, B., Hutchinson, J. R., and Shefelbine, S. J.: BoneJ: free and extensible bone image analysis in ImageJ, Bone, 47, 1076-1079, https://doi.org/10.1016/j.bone.2010.08.023, 2010.

Engels, J. P.: The catazonal polymetamorphic rocks of Cabo Ortegal (NW Spain), a structural and petrofabric study, Leidse Geologische Mededelingen, 48, 83-133, 1972.

Faure, M., Bé Mézème, E., Cocherie, A., Rossi, P., Chemenda, A., and Boutelier, D.: Devonian geodynamic evolution of the Variscan Belt, insights from the French Massif Central and Massif Armoricain, Tectonics, 27, TC2005, https://doi.org/10.1029/2007TC002115, 2008.

Fay, C., Bell, T. H., and Hobbs, B. E.: Porphyroblast rotation versus nonrotation: Conflict resolution!, Geology, 36, 307-310, 2008.

Felix, C. and Fransolet, A. M.: Pseudomorphes à épidote s.l., paragonite, muscovite s.l., chlorite, albite; de porphyroblastes de lawsonite (?) dans les glaucophanites de l'île de groix (bretagne France), Annales de la Société Geologique de Belgique, 95, 323 334, 1972.

Hayward, N.: Determination of early fold axis orientations in multiply deformed rocks using porphyroblast inclusion trails, Tectonophysics, 179, 353-369, 1990.

Hayward, N.: Microstructural analysis of the classical spiral garnet porphyroblasts of south-east Vermont: evidence for non-rotation, J. Metamorph. Geol., 10, 567-587, 1992.

Huddlestone-Holmes, C. R. and Ketcham, R. A.: An X-ray computed tomography study of inclusion trail orientations in multiple porphyroblasts from a single sample, Tectonophysics, 480 , 305-320, 2010. 
Jammes, S., Manatschal, G., Lavier, L., and Masini, E.: Tectonosedimentary evolution related to extreme crustal thinning ahead of a propagating ocean: example of the western Pyrenees, Tectonics, 28, TC4012, https://doi.org/10.1029/2008TC002406, 2009.

Kim, H. S. and Ree, J. H.: Permo-Triassic changes in bulk crustal shortening direction during deformation and metamorphism of the Taebaeksan Basin, South Korea using foliation intersection/inflection axes: Implications for tectonic movement at the eastern margin of Eurasia during the Songrim (Indosinian) orogeny, Tectonophysics, 587, 133-145, https://doi.org/10.1016/j.tecto.2012.08.033, 2013.

Lagarde, J. L.: La déformation des roches dans les domaines àschistosité subhorizontale. Applications à la nappe du Canigou-Roc de France (Pyrénées orientales) et au complexe crystallophyllien de Champtoceaux (Massif armoricain), $\mathrm{PhD}$ thesis, Université de Rennes, 170 pp., 1980.

Li, B. and Massonne, H. J.: Contrasting metamorphic evolution of metapelites from the Malpica-Tuy unit and the underlying socalled parautochthon at the coast of NW Spain, Lithos, 286-287, 92-108, https://doi.org/10.1016/j.lithos.2017.06.003, 2017.

Lucks, H., Schulz, B., Audren, C., and Triboulet, C.: Variscan pressure-temperature evolution of garnet pyroxenites and amphibolites in the Baie d'Audierne metamorphic series, Brittany (France), edited by: Martínez Catalán, J. R., Hatcher, R. D., Arenas, R., and Díaz García, F., Variscan-Appalachian dynamics: The building of the late Paleozoic basement: Boulder, Colorado, Geological Society of America Special Paper 364, 89-103, 2002.

Mardia, K. V. and Jupp, P. E.: Directional Statistics, John Wiley \& Sons., 456 pp., 2009.

Mares, V. M.: Structural development of the Soldiers Cap Group in the Eastern Fold Belt of the Mt Isa Inlier: a successive of horizontal and vertical deformation events and large-scale shearing, Austral. J. Earth Sci., 45, 373-387, 1998.

Martínez Catalán, J. R.: Are the oroclines of the Variscan belt related to late Variscan strike-slip tectonics?, Terra Nova, 23, 241247, https://doi.org/10.1111/j.1365-3121.2011.01005.x, 2011.

Martínez Catalaín, J. R., Arenas, R., Díaz García, F., Rubio Pascual, F. J., Abati, J., and Marquínez, J.: Variscan exhumation of a subducted Palaeozoic continental margin: the basal units of the Ordenes Complex, Galicia, NW Spain, Tectonics, 15, 106-121, 1996.

Martínez Catalán, J. R., Arenas, R., Díaz García, F., and Abati, J.: Variscan accretionary complex of northwest Iberia: Terrane correlation and succession of tectonothermal events, Geology, 25, 1103-1106, 1997.

Matte, P.: The Variscan collage and orogeny (480-290 Ma) and the tectonic definition of the Armorica microplate: a review, Terra Nova, 13, 122-128, 2001.

Merle, O.: The building of the central Swiss Alps: An experimental approach, Tectonophysics, 165, 41-56, 1989.

Munro, M. A. and Blenkinsop, T. G.: MARD - A moving average rose diagram application for the geosciences, Comput. Geosci., 49, 112-120, https://doi.org/10.1016/j.cageo.2012.07.012, 2012.

Nirrengarten, M., Manatschal, G., Tugend, J., Kusznir, N.J., and Sauter, D.: Kinematic Evolution of the Southern North Atlantic: Implications for the Formation of Hyperextended Rift Systems, Tectonics 37, 89-118, https://doi.org/10.1002/2017TC004495, 2018.
Philippon, M., Brun, J. P., and Gueydan, F.: Kinematic records of subduction and exhumation in the Île de Groix blueschists (Hercynian belt; Western France), J. Struct. Geol., 31, 1308-1321, 2009.

Quinquis, H.: Schistes bleus et déformation progressive: l'exemple de l'Île de Groix (Massif Armoricain), Université de Rennes, 1, 1980.

Quinquis, H. and Choukroune, P.: The Ile de Groix blueschists in the Hercynian chain - kinematical implications, B. Soc. Geol. Fr., 2, 409-418, 1981.

Quinquis, H., Audren, C., Brun, J. P., and Cobbold, P. R.: Intense shear in Ile de Groix blueschists and compatibility with subduction or obduction, Nature, Lond., 273, 43-45, 1978.

Rosenfeld, J. L.: Rotated garnets in metamorphic rocks, Geological Society of America, Special Paper 129, 102 pp., 1970.

Sayab, M.: Microstructural evidence for N-S shortening in the Mount Isa Inlier (NW Queensland, Australia): the preservation of early W-E-trending foliations in porphyroblasts revealed by independent 3D measurement techniques, J. Struct. Geol., 27, 1445-1468, 2005.

Sayab, M., Aerden, D., Kuva, J., and Hassan, W. U.: Tectonic evolution of the Karakoram metamorphic complex (NW Himalayas) reflected in the 3D structures of spiral garnets: Insights from X-ray computed micro-tomography, Geosci. Front., 3, 101113, https://doi.org/10.1016/j.gsf.2020.11.010, 2021.

Shah, S. Z., Sayab, M., Aerden, D. G. A. M., and Asif-Kahn, M.: Foliation intersection axes preserved in garnet porphyroblasts from the Swat area, NW Himalaya: A record of successive crustal shortening directions between the Indian plate and Kohistan-Ladakh Island Arc, Tectonophysics, 509, 14-32, 2011.

Shelley, D. and Bossieère, G.: Ile de groix: retrogression and structural developments in an extensional régime, J. Struct. Geol., 21, 1441-1455, 1999.

Schindelin, J., Arganda-Carreras, I., Frise, E., Kaynig, V., Longair, M., Pietzsch, T., Preibisch, S., Rueden, C., Saalfeld, S., Schmid, B., Tinevez, J. Y., White, D. J., Hartenstein, V., Eliceiri, K., Tomancak, P., and Cardona, A.: Fiji: an open-source platform for biological-image analysis, Nat. Methods, 9, 676-682, 2012.

Schulz, B., Audren, C., and Triboulet, C.: Regional vs contact metamorphism of garnet metapelites in the vicinity of Late Variscan granites (Central Armorican Domain, Brittany, France), Geol. Rundsch., 87, 78-93, 1998.

Schulz, B., Triboulet, C., Audren, C., Pfeifer, H. R., and Gilg, A.: Two-stage prograde and retrograde Variscan metamorphism of glaucophane-eclogites, blueschists and greenschists from Ile de Groix (Brittany, France), Int. J. Earth Sci., 90, 871-889, 2001.

Spry, A.: The origin and sigdicance of snowball structure in garnet, J. Petrol., 4, 211-222, 1963.

Stallard, A. and Hickey, K.: Shear zone vs folding origin for spiral inclusion trails in the Canton Schist, J. Struct. Geol., 23, 18451864, 2001.

Stallard, A. R., Hickey, K. A., and Upton, G. J.: Measurement and correlation of microstructures: the case of foliation intersection axes, J. Metamorph. Geol., 21, 241-252, 2003.

Triboulet, C.: Les glaucophanites et roches associeés de l'île de Groix (Morbihan, France): étude minéralogique et pétrogénétique, Contrib. Mineral. Petr., 45, 65-90, 1974.

Triboulet, C.: Subglaucophanic greenschists from Le-Pouldu, a transitional area between blueschists and amphibolites from a 
paleozoic single metamorphic belt in south Brittany, France, Comptes Rendus de l'Academie des Sciences serie II, 315, 697703, 1992.

Van Zuuren, A.: Structural petrology of an area near Santiago de Compostella (NW Spain), Leidse Geologische Mededelingen, $45,1-71,1969$.
Zhang, Q. and Fossen, H.: The dilemma of asymmetric porphyroclast systems and sense of shear, J. Struct. Geol., 130, 103893, https://doi.org/10.1016/j.jsg.2019.103893, 2020.

Zwart, H.: On the determination of polymorphic mineral associations and its application to the Bosost area (central Pyrenees), Geologisches Rundschau, 52, 38-65, 1962. 